\title{
ERK/MAPK Signaling Is Required for Pathway-Specific Striatal Motor Functions
}

\author{
Scott R. Hutton, ${ }^{1}$ James M. Otis, ${ }^{1}$ Erin M. Kim, ${ }^{1}$ Yashna Lamsal, ${ }^{1}$ Garret D. Stuber, ${ }^{1,2,3}$ and William D. Snider ${ }^{1}$ \\ ${ }^{1}$ Neuroscience Center, ${ }^{2}$ Department of Psychiatry, and ${ }^{3}$ Department of Cell Biology and Physiology, University of North Carolina at Chapel Hill, Chapel Hill, \\ North Carolina 27599
}

The ERK/MAPK intracellular signaling pathway is hypothesized to be a key regulator of striatal activity via modulation of synaptic plasticity and gene transcription. However, prior investigations into striatal ERK/MAPK functions have yielded conflicting results. Further, these studies have not delineated the cell-type-specific roles of ERK/MAPK signaling due to the reliance on globally administered pharmacological ERK/MAPK inhibitors and the use of genetic models that only partially reduce total ERK/MAPK activity. Here, we generated mouse models in which ERK/MAPK signaling was completely abolished in each of the two distinct classes of medium spiny neurons (MSNs). ERK/MAPK deletion in D1R-MSNs (direct pathway) resulted in decreased locomotor behavior, reduced weight gain, and early postnatal lethality. In contrast, loss of ERK/MAPK signaling in D2R-MSNs (indirect pathway) resulted in a profound hyperlocomotor phenotype. ERK/MAPK-deficient D2R-MSNs exhibited a significant reduction in dendritic spine density, markedly suppressed electrical excitability, and suppression of activity-associated gene expression even after pharmacological stimulation. Our results demonstrate the importance of ERK/MAPK signaling in governing the motor functions of the striatal direct and indirect pathways. Our data further show a critical role for ERK in maintaining the excitability and plasticity of D2R-MSNs.

Key words: activity-induced gene expression; basal ganglia; dendritic spine; hyperlocomotion; MAP kinase; medium spiny neuron

Significance Statement

Alterations in ERK/MAPK activity are associated with drug abuse, as well as neuropsychiatric and movement disorders. However, genetic evidence defining the functions of ERK/MAPK signaling in striatum-related neurophysiology and behavior is lacking. We show that loss of ERK/MAPK signaling leads to pathway-specific alterations in motor function, reduced neuronal excitability, and the inability of medium spiny neurons to regulate activity-induced gene expression. Our results underscore the potential importance of the ERK/MAPK pathway in human movement disorders.

\section{Introduction}

The basal ganglia govern a vast array of psychomotor behaviors (Nelson and Kreitzer, 2014; Graybiel and Grafton, 2015). Sensorimotor information is integrated into the basal ganglia via the striatum, where glutamatergic and dopaminergic inputs converge onto two distinct classes of medium spiny neurons (MSNs) (Gerfen et al., 1990; Kawaguchi et al., 1990; Gong et al., 2007;

Received Feb. 20, 2017; revised May 29, 2017; accepted July 1, 2017.

Author contributions: S.R.H., J.M.O., G.D.S., and W.D.S. designed research; S.R.H., J.M.O., E.M.K., and Y.L. performed research; S.R.H., J.M.O., E.M.K., and Y.L. analyzed data; S.R.H., J.M.O., G.D.S., and W.D.S. wrote the paper.

This work was supported by the National Institutes of Health (NIH Grants R01-NS031768 to W.D.S., Grant R01DA032750 to G.D.S., and Grant F32-DA041184 to J.M.O.). We thank the UNC Confocal and Multiphoton Imaging Core (supported by the NIH National Institute of Neurological Disorders and Stroke Center Grant P30 NS045892), the UNC Functional Genomics Core, the UNC Viral Vector Core, and Yaohong Wu for technical assistance.

The authors declare no competing financial interests.

Correspondence should be addressed to William D. Snider, Neuroscience Center, 115 Mason Farm Rd., NRB Rm 8109D, CB \#7250, University of North Carolina, Chapel Hill, NC 27599. E-mail: william_snider@med.unc.edu.

DOI:10.1523/JNEUROSCI.0473-17.2017

Copyright $\odot 2017$ the authors $\quad 0270-6474 / 17 / 378102-14 \$ 15.00 / 0$
Cerovic et al., 2013). Direct-pathway MSNs (D1R-MSNs) express the dopamine 1 receptor (D1) and largely project to the substantia nigra reticulata $(\mathrm{SNr})$ and globus pallidus internae (GPi). Indirect-pathway MSNs (D2R-MSNs) express dopamine 2 (D2) and adenosine A2a (A2a) receptors and predominantly target the globus pallidus externae (GPe). Experimental evidence suggests that D1R-MSN and D2R-MSN activities have opposing actions. In the motor system, stimulation of the direct pathway elicits activation of motor behaviors, whereas stimulation of the indirect pathway inhibits motor activity (Kravitz et al., 2010; Farrell et al., 2013). Silencing each pathway has the converse effects (Durieux et al., 2009; Hikida et al., 2010).

The convergence of glutamatergic and dopaminergic signaling onto MSNs leads to long-term alterations in neuronal excitability, changes in activity-induced gene expression and modulation of dendritic spine density (Cerovic et al., 2013; Nelson and Kreitzer, 2014). A major signaling pathway implicated in mediating these long-lasting changes is ERK/MAPK (ERK) (Thomas and Huganir, 2004; Pascoli et al., 2014). Glutamatergic stimulation leads to 
ERK activation through a NMDAR-mediated calciumdependent mechanism (Krapivinsky et al., 2003; Mao et al., 2004; Valjent et al., 2005), whereas dopamine differentially regulates ERK activity based on the dopamine receptor subtypes expressed by the neuron (Calabresi et al., 2014). Therefore, ERK is hypothesized to initiate appropriate cellular responses to patterned activity from different classes of presynaptic input (Valjent et al., 2005; Girault et al., 2007).

Prior work has implicated ERK activity in striatally mediated locomotor and adaptive behaviors, but these studies have produced conflicting results (Girault et al., 2007; Cerovic et al., 2013; Calabresi et al., 2014). Pharmacological inhibition of ERK signaling prevented consolidation of motor skill learning, instrumental learning, and habit formation (Bureau et al., 2010; Shiflett et al., 2010; Shiflett and Balleine, 2011). In contrast, loss of ERK1 in germline knock-out mice showed surprising effects, including baseline hyperactivity, increased synaptic plasticity, enhanced learning, and enhanced locomotor response to cocaine (Selcher et al., 2001; Mazzucchelli et al., 2002; Ferguson et al., 2006; Engel et al., 2009). This disparity has been attributed to increased ERK2 function in ERK1-deleted animals, emphasizing the need to delete both ERK1 and ERK2 in genetic studies (Mazzucchelli et al., 2002; Ferguson et al., 2006). Moreover, prior genetic and pharmacological studies have failed to target ERK inhibition to specific striatal cell types, further confounding interpretations of ERK function. Therefore, despite the evidence supporting the importance of ERK signaling to striatal functions and adaptations, pathway-specific functions of ERK signaling have not been identified (Fasano and Brambilla, 2011).

Here, we have delineated cell-type-specific functions of ERK signaling by conditionally deleting ERK2 on an ERK1-null background using D1-Cre and D2-Cre lines (Gong et al., 2007). Loss of ERK in D1R-MSNs led to decreased locomotor activity, failure to thrive, and early postnatal lethality, precluding further analysis of the mice. Deletion of ERK in D2R-MSNs resulted in a hyperlocomotor phenotype that is comparable to D2-specific cell ablation studies reported previously (Durieux et al., 2009). We report, for the first time, physiological analysis of D2R-MSNs in the setting of complete ERK deletion. ERK-deleted D2R-MSNs are remarkably hypoexcitable, showing reduced frequencies of postsynaptic currents and major reductions in intrinsic excitability. Finally, expression of immediate early and plasticity-associated genes are markedly reduced in ERK-deleted D2R-MSNs both at baseline and in response to pharmacological stimulation. We conclude that ERK signaling is required for pathway-specific striatal motor functions. Furthermore, ERK signaling is essential to the excitability and activity-regulated gene expression of D2RMSNs.

\section{Materials and Methods}

Animals. Animals were used and maintained in accordance with the National Institutes of Health's Guide for the Care and Use of Laboratory Animals and all protocols were approved by the Institutional Animal Care and Use Committee at the University of North Carolina-Chapel Hill (UNC). Drd2-EGFP, Drd1a(EY262)-Cre, Drd2(EY43)-Cre, and Adora2a-Cre mice were purchased from the Mutant Mouse Regional Resource Center (MMRRC) (Gong et al., 2007). Erk1 ${ }^{-1-}\left(\right.$ Mapk3 $^{-1-}$ ) and Erk2 $2^{\text {loxP/loxP }}($ Mapk1 loxP/loxP $)$ mice (Nekrasova et al., 2005; Samuels et al., 2008) were kindly provided by G. Landreth (Case Western Reserve University, Cleveland, OH). Drd1 a tdTomato (Ade et al., 2011), Ai3-EYFP, and Ai9-tdTomato (Madisen et al., 2010) reporter lines were purchased from The Jackson Laboratory. All animals were maintained on a C57BL/6J background. For birth-dating, the day of birth was recorded as postnatal day $0(\mathrm{P} 0)$. All experiments were replicated independently with a minimum of three animals per condition. Power analysis was conducted on preliminary samples to determine sample size using StatMate software (GraphPad). We chose a significance $\alpha$ value of 0.05 and a power value of 0.8 . Mixed-sex samples were used for analyses unless otherwise noted. For all experiments, Erk1 $1^{-1-} ; E r k 2^{\text {loxP/loxP }}$ littermate controls were used for comparison unless otherwise specified. For genotyping, DNA was extracted from tail or toe samples and PCR analysis was conducted using standard techniques. Genotyping primer sequences were as follows: D1-Cre: Fwd-5'-GCTATGGAGATGCTCCTGATGG AA-3', Rev-5'-CGGCAAACGGACAGAAGCATT-3'; D2-Cre: Fwd-5' GTGCGTCAGCATTTGGAGCAA-3', Rev-5' -CGGCAAACGGACAGA AGCATT-3'; Adora2a-Cre: Fwd-5'-CGTGAGAAAGCCTTTGGGAA GCT-3', Rev-5'-CGGCAAACGGACAGAAGCATT-3'; D2-GFP: Fwd5'-GAGGAAGCATGCCTTGAAAA-3'， Rev-5'-TGGTGCAGATGAAC TTCAGG-3'; ERK1 KO: Fwd-5'-AAGCAAGGCTAAGCCGTACC-3', Rev (WT)-5' -AAGGTTAACATCCGGTCCAGCA-3', Rev(Mut)-5' -CA TGCTCCAGACTGCCTTGG-3'; ERK2 Flox: Fwd-5'-AGCCAACAATC CCAAACCTG-3', Rev-5'-GGCTGCAACCATCTCACAAT-3'; Ai3: Fwd(WT)-5' -AAGGGAGCTGCAGTGGAGTA-3', Rev(WT)-5' -CCG AAAATCTGTGGGAAGTC-3', Fwd (Mut)-5'-ACATGGTCCTGCTG GAGTTC-3', Rev(Mut)-5'-GGCATTAAAGCAGCGTATCC-3'; Ai9: Fwd(WT)-5' -AAGGGAGCTGCAGTGGAGTA-3; Rev(WT)-5' -CCGA AAATCTGTGGGAAGTC-3', Fwd (Mut)-5'-GGCATTAAAGCAGCG TATCC-3', Rev(Mut)-5'-CTGTTCCTGTACGGCATGG; D1 $1^{\text {tdTomato: }}$ Fwd-5' -CTTCTGAGGCGGAAAGAACC-3', Rev-5' -TTTCTGATTGA GAGCATTCG.

Acute tissue extraction. Mice were killed via cervical dislocation and the brains immediately extracted and rinsed in ice-cold $1 \times$ PBS. The brains were then placed in a chilled acrylic brain matrix (Ted Pella) and 1-mmthick coronal slices were made using a razor blade. Slices were then placed in chilled $1 \times$ PBS and, using a $1 \mathrm{~mm}$ micropunch (Ted Pella), 2-3 tissue punches were extracted from dorsal striatum from each hemisphere for analysis using gene expression profiling (see below).

Gene expression profiling. Striatal punches were extracted from three littermate control and three mutant P17 male mice generated from three independent litters. Total RNA was extracted using TRIzol reagent (Invitrogen), followed by mRNA extraction using an RNeasy Mini Kit (Qiagen) according to the manufacturer's instructions. Quantity of extracted mRNA was analyzed using a Nanodrop (ND1000) spectrophotometer and the quality was verified with an Agilent Technologies 2100 Bioanalyzer. The RNA was then amplified, labeled, and hybridized to an Affymetrix Clariom D Array in the UNC Functional Genomics Core using the manufacturer's protocol. Gene-level differential expression analysis was conducted using Transcriptome Analysis Console version 3.0 (Affymetrix) with the default algorithm parameters for the Clariom D Array. $\log _{2}$ sample values were used to determine differential gene expression and $p$-values. Genes were considered upregulated or downregulated if there was a \pm 1.5 -fold difference in expression levels compared with control samples. Changes were considered significant at $p \leq 0.05$. The data discussed herein have been deposited in NCBI's Gene Expression Omnibus (Edgar et al., 2002) and are accessible through GEO Series accession number GSE93844 (https://www.ncbi.nlm.nih.gov/geo/query/ acc.cgi? acc $=$ GSE93844).

Tissue fixation and preparation. Mice were anesthetized with a $2.5 \%$ Avertin solution (Sigma-Aldrich) and then transcardially perfused with $4 \%$ paraformaldehyde/PBS (Sigma-Aldrich). Brains were then postfixed in $4 \%$ paraformaldehyde solution at $4^{\circ} \mathrm{C}$ overnight. Tissue was mounted in $4 \%$ low-melt agarose and $80 \mu \mathrm{m}$ coronal or sagittal sections were generated using a vibratome (Leica).

Immunohistochemistry. Brain sections were rinsed in $1 \times \mathrm{PBS}$ and then blocked with $5 \%$ normal donkey serum $/ 0.1 \%$ Triton X-100 in $1 \times$ PBS (PBS-T) for $1 \mathrm{~h}$ at room temperature. Sections were then incubated in primary antibody in PBS-T for $48 \mathrm{~h}$ at $4^{\circ} \mathrm{C}$ with slight agitation. After primary incubation, slices were rinsed with PBS-T and then incubated in fluorescent secondary antibodies in PBS-T for $24 \mathrm{~h}$ at $4^{\circ} \mathrm{C}$. Sections were again rinsed with PBS-T and then mounted on Superfrost/Plus slides (Fisher Scientific) using Prolong Diamond Mountant (Life Technologies) before coverslipping. 
Antibodies. Primary antibodies used for Western blot were rabbit phospho-MAPK1/3(ERK1/2) (Thr202/Tyr204) and rabbit MAPK1/ 3(ERK1/2) (Cell Signaling Technology). Primary antibodies used for immunohistochemistry were as follows: rabbit Erk2 and rat Ctip2 (1:500, Abcam), rabbit c-FOS (1:500; Cell Signaling Technology), chicken GFP (1:1000; Aves Laboratories), rabbit RFP and mouse RFP (1:250; Rockland), and rabbit ARC (1:1000; Synaptic Systems). Secondary antibodies used: goat/chicken/donkey Alexa Fluor 488, goat/donkey Alexa Fluor 568, and goat/donkey Alexa Fluor 647 (1:1000; Life Technologies).

Viral injections. P1 mice were individually cryo-anesthetized on wet ice for $3 \mathrm{~min}$ and then immediately injected with $200 \mathrm{nl}$ of virus solution using a $5 \mu \mathrm{l}$ Hamilton syringe fitted with a 32 gauge beveled needle mounted to a stereotaxic arm. AAV8-CAG-GFP (UNC Vector Core, Chapel Hill, NC) virus was prepared by diluting concentrated virus with PBS $+5 \%$ sorbitol $+0.1 \%$ Fast Green (for visualization) for a final concentration of $5 \times 10^{8}$ molecules $/ \mu$ l. Unilateral injections were made into the striatum. After the injection, pups were placed on a heating pad until they recovered. Upon recovering, all pups were then placed back into their home cage.

Locomotor activity. Naive animals were evaluated for spontaneous locomotor activity using a $45 \times 45 \mathrm{~cm}$ Plexiglass arena and Ethovision XT 11.5 (Noldus) video-tracking software. Distance traveled was measured using Lowess smoothing to minimize tracking fluctuations. All animals were acclimated to the testing room $3 \mathrm{~h}$ before locomotor testing.

Catalepsy. Two-month-old mice were injected with $1 \mathrm{mg} / \mathrm{kg}$ haloperidol $(0.1 \mathrm{mg} / \mathrm{ml}) 1 \mathrm{~h}$ before evaluation of cataleptic behavior. To test catalepsy, both front paws were placed on a horizontal bar mounted $4 \mathrm{~cm}$ above the testing chamber floor while both hindpaws remained on the floor. The time taken to remove both forepaws from the bar or move both paws sideways on the bar was recorded. Maximum trial times were 300 s. Mice were tested in three consecutive trials unless the maximum cutoff time was achieved in one of the trials. Catalepsy was determined by taking the average of the three trials or $300 \mathrm{~s}$ if the maximum was achieved. Haloperidol bromide (Sigma-Aldrich) stock solution was dissolved in $(25 \mu \mathrm{l}$ of glacial acetic acid diluted to $1 \mathrm{mg} / \mathrm{ml}$ with $0.9 \%$ saline and buffered to $\mathrm{pH} 6.5$ with $1 \mathrm{~N} \mathrm{NaOH})$. Stock solution was then diluted with $0.9 \%$ saline to generate a $0.1 \mathrm{mg} / \mathrm{ml}$ working solution. Injection vehicle solution was generated in the same manner without the addition of haloperidol.

Imaging. All images were acquired using a model 780 confocal microscope with ZEN 2011 software (both Carl Zeiss). For comparative studies, image acquisition settings were maintained across all samples. For dendritic spine analysis, five D1R-MSNs and five D2R-MSNs were analyzed per animal from the dorsal striatum. Labeled MSNs were selected randomly for analysis from a group that showed no dendritic overlap with neighboring GFP-labeled cells. Three secondary or tertiary dendrites were then analyzed per cell. For best resolution, only dendrites that were located between 5 and $20 \mu \mathrm{m}$ from the slice surface and that displayed minimal variation in the horizontal plane were analyzed. All imaged dendrites could be traced continuously back to their respective soma. 3D $42.5 \times 42.5 \mu \mathrm{m} z$-stack images of dendritic segments were acquired using $0.388 \mu \mathrm{m}$ optical sections. After acquisition, images were coded and analysis was conducted by a blinded observer. 3D reconstruction and spine quantification were conducted using Neurolucida 10 software (MBF Bioscience). Dendritic spines were traced manually throughout each $3 \mathrm{D}$ reconstruction image and quantified automatically by the software program.

Cell quantification. Cell quantification was performed on $637 \times 637$ $\mu \mathrm{m}$ RGB images acquired from anatomically matched slices of dorsal striatum. All image analysis was conducted by an observer blinded to sample genotypes using Photoshop CS3 software (Adobe). The D $1^{\text {tdTomato }}$ fluorescent reporter was used to identify D1R-MSNs (red fluorescence) and D2R-MSNs (no fluorescence). For each image, all CTIP2-positive MSNs were counted. For the assessment of c-FOS- and ARC-expressing cells, individual MSNs were first selected based upon Ctip2 (blue channel) labeling using the "quick selection tool." Next, each selected cell was then categorized as a D1R-MSN or D2R-MSN based upon whether it expressed D $1^{\text {tdTomato }}$ fluorescence (red channel). Last, c-FOS or ARC (green channel) was selected and the integrated pixel intensity and area for each cell was recorded automatically by the software. The average pixel density (pixel intensity/area) was calculated for each selected cell. A cell was considered positive for c-FOS or ARC expression if the average pixel density was $>2$-fold higher than background. The assessment of ERK2 expression was performed similarly except that ERK2 expression was determined manually by the observer. For analysis of D2GFPA2aCre;Ai9 experiments, D2GFP, A2aCre;Ai9, and colabeled cells were counted manually using the count tool in Photoshop.

Patch-clamp electrophysiology. For all electrophysiology analyses, the experimenter was blinded to sample genotypes. Mice were anesthetized with pentobarbital and transcardial perfusions were performed using an ice-cold sucrose cutting solution $\left(0-1^{\circ} \mathrm{C}\right)$ containing the following (in $\mathrm{mm}$ ): 225 sucrose, $119 \mathrm{NaCl}, 1.0 \mathrm{NaH}_{2} \mathrm{PO}_{4}, 4.9 \mathrm{MgCl}_{2}, 0.1 \mathrm{CaCl}_{2}, 26.2$ $\mathrm{NaHCO}_{3}$, and 1.25 glucose, 305-308 mOsm. Brains were then removed and submerged in the cutting solution and $300-\mu \mathrm{m}$-thick coronal sections were made using a vibrating blade (Leica, VT 1200). Slices were then placed in warm aCSF $\left(32^{\circ} \mathrm{C}\right.$ ) containing the following (in mM): 119 $\mathrm{NaCl}, 2.5 \mathrm{KCl}, 1.0 \mathrm{NaH}_{2} \mathrm{PO}_{4}, 1.3 \mathrm{MgCl}, 2.5 \mathrm{CaCl}_{2}, 26.2 \mathrm{NaHCO}_{3}$, and 15 glucose, $305 \mathrm{mOsm}$. After at least $1 \mathrm{~h}$ of recovery, slices were perfused with warm aCSF $\left(32^{\circ} \mathrm{C}\right)$ containing no pharmacology (excitability recordings) or with $0.5 \mu \mathrm{M}$ tetrodotoxin [miniature EPSC (mEPSC) and miniature IPSC (mIPSC) recordings; Sigma-Aldrich]. Neurons were visualized using differential interference contrast through an upright $40 \times$ water-immersion objective mounted to an upright microscope (Olympus BX51WI). Fluorescent imaging using a mercury lamp (Olympus U-RFL-T) was used to identify dd $^{\text {Tomato }}$-positive (D1) versus $\mathrm{td}^{\text {Tomato }}$ negative (D2) MSNs.

Synaptic connectivity was measured through mEPSC and mIPSC recordings obtained using glass electrodes (3-5 M $\Omega$ ) back-filled with cesium methylsulfonate internal solution containing the following (in mM): 117 Cs methanesulfonic acid, 20 HEPES, $2.8 \mathrm{NaCl}, 5$ TEA, 2 ATP, and 0.2 GTP, pH 7.35, mOsm 280. mEPSCs were obtained by holding neurons at $-70 \mathrm{mV}$ for $5 \mathrm{~min}$ and $\mathrm{mIPSC}$ were obtained by holding neurons at $+10 \mathrm{mV}$ for $5 \mathrm{~min}$. Data acquisition for mEPSCs and mIPSCs occurred at $1 \mathrm{kHz}$ sampling rate through a MultiClamp 700B amplifier connected to a Digidata 1440A digitizer (Molecular Devices).

Excitability recordings were obtained using glass electrodes (3-5 M $\Omega$ ) back-filled with a potassium gluconate internal solution containing the following (in mM): $130 \mathrm{~K}$ gluconate, $10 \mathrm{KCl}, 10 \mathrm{HEPES}, 10 \mathrm{EGTA}, 2 \mathrm{MgCl}_{2}$, 2 ATP, and 0.2 GTP, $280 \mathrm{mOsm}$. Intrinsic neuronal excitability was evaluated by depolarizing each neuron using $800 \mathrm{~ms}$ current steps ( 0 to $500 \mathrm{pA} ; 50$ pA steps). Rheobase was also evaluated by depolarizing each neuron in $50 \mathrm{~ms}$ current steps (0 to $1000 \mathrm{pA} ; 10 \mathrm{pA}$ steps). Data acquisition for excitability recordings occurred at a $10 \mathrm{kHz}$ sampling rate. Excitability data were analyzed using a threshold analysis (Clampfit 10.3).

Statistical analysis. All data were analyzed using Prism version 6.0 software (GraphPad). Data are presented as mean \pm SEM unless otherwise noted. For direct comparisons, statistical significance was determined using a two-tailed $t$ test with Welch's correction. For studies requiring ANOVA, methods used for post hoc analysis to determine statistical significance are mentioned in the text and figure legends.

\section{Results}

Cell-type-specific deletion of ERK in D1R- and D2R-MSNs

ERK signaling has been proposed to be a key integrator of dopaminergic and glutamatergic input onto MSNs and a critical modulator of neuronal plasticity (Girault et al., 2007; Fasano and Brambilla, 2011). To understand the functional role of ERK signaling in the striatum, we generated mutant mice in which Erk1 and Erk2 genes were deleted in specific populations of MSNs. Both genes require deletion due to functional redundancy between ERK1 and ERK2 (Selcher et al., 2001; Mazzucchelli et al., 2002). To accomplish cell-type-specific deletion, we crossed Erk1-1Erk2 ${ }^{\text {loxP/loxP }}$ mice (Nekrasova et al., 2005; Samuels et al., 2008) with the well documented D1-Cre and D2-Cre lines (Gong et al., 2007). The resulting Erk1 $1^{-/-} E r k 2^{\text {loxP/loxP}}:$ D1Cre (ERK:D1) and Erk1 ${ }^{-1-}$ Erk2 $2^{\text {loxP/loxP }}: D 2 C r e(E R K: D 2)$ lines were germline null for ERK1 and lacked ERK2 expression in D1R-MSNs and D2R- 
A D1totomato/ERK2

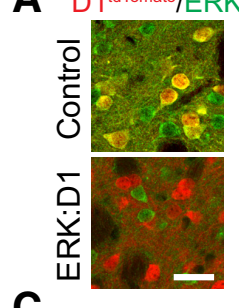

C
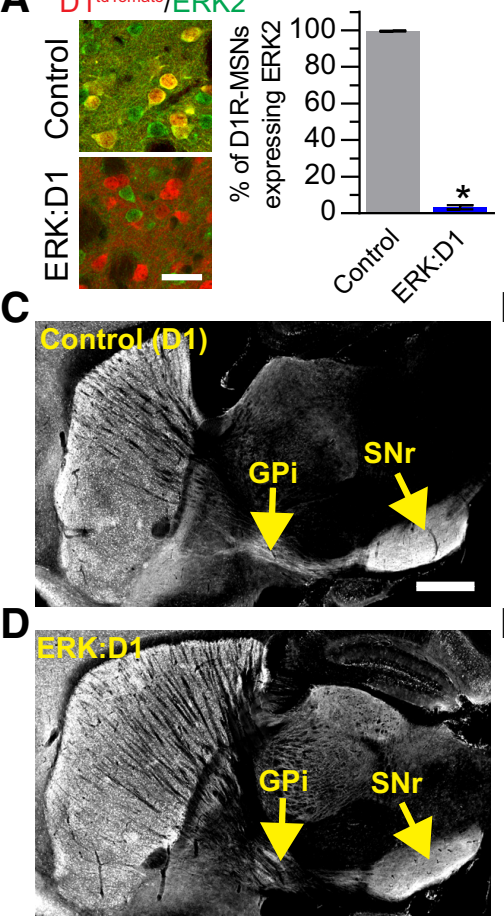

G

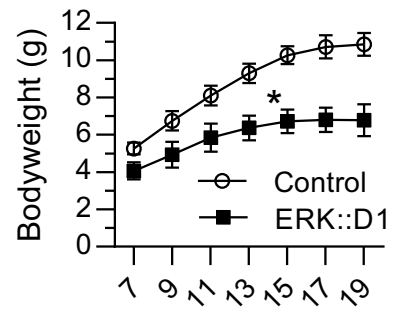

Age (Days)
B D1tdomato/ERK2
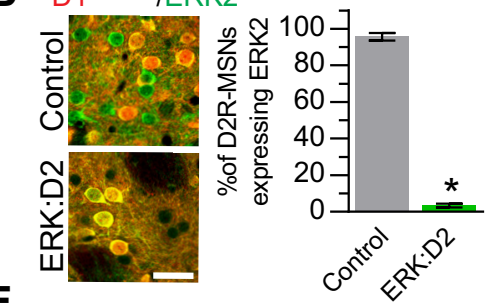

E

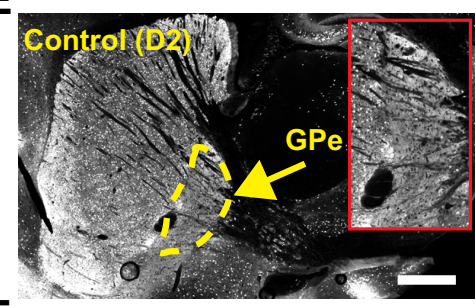

\section{$\mathbf{F}$}

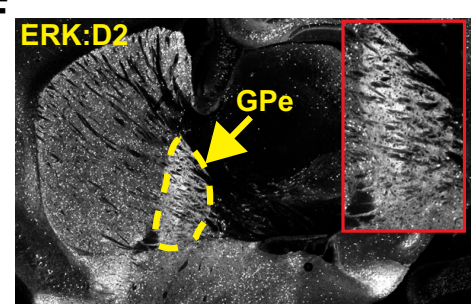

H

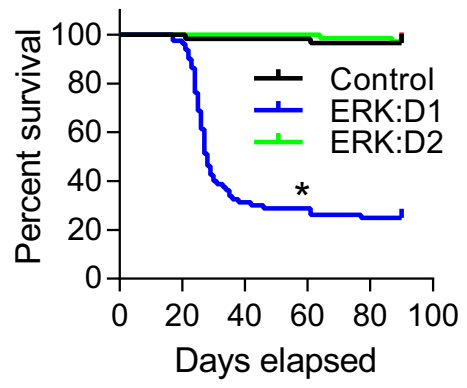

Figure 1. ERK-deficient MSNs show proper targeting of axonal projections. $\boldsymbol{A}$, Quantification of the relative percentage of ERK2-positive D1R-MSNs in control and ERK:D1 mutant mice at P21. ERK2 (green) is coexpressed with D1 ${ }^{\text {tdTomato }}$ (red) in D1RMSNs of littermate control mice, but is lost in virtually all D1R-MSNs of ERK:D1 mutant mice $\left(^{*} p<0.001 ; n=3\right.$ mice/genotype, 150 cells/mouse). Scale bar, $50 \mu \mathrm{m}$. B, Quantification of the percentage of ERK2-postive D2R-MSNs in littermate control and ERK:D2 mutant mice at P21. ERK2 (green) is expressed in in both D1 ${ }^{\text {tdTomato }}$-positive D1R-MSNs and D1 ${ }^{\text {tdTomato }}$-negative D2RMSNs of littermate control mice, but is lost in virtually all D1 ${ }^{\text {tdTomato }}$-negative D2R-MSNs of ERK:D2 mutant mice $\left({ }^{*} p<0.001 ; n=\right.$ 3 mice/genotype, 150 cells/mouse). Scale bar, $50 \mu \mathrm{m}$. C, D, Control (ERK ${ }^{-/-}$;ERK2 ${ }^{\text {w/w.w }}:$ D ${ }^{\text {Cre }}$ ) and ERK:D1 mutant mice were backcrossed with Cre-dependent fluorescent reporter Ai3 mice to label all D1R-MSN projections with enhanced yellow fluorescent protein (eYFP). Normal D1R axon targeting to the GPi and SNr is observed in control (C) and ERK:D1 mutant (D) mice. Scale bar, $1 \mathrm{~mm} . \boldsymbol{E}, \boldsymbol{F}$, Control (ERK ${ }^{-1-} ;$ ERK2 ${ }^{\text {w/w }}:$ D2 ${ }^{\text {Cre }}$ ) and ERK:D2 mutant mice were backcrossed with Ai3 mice to label D2R-MSN axonal projections with eYFP. Normal D2R axon targeting to the GPe is observed in control $(\boldsymbol{E})$ and ERK:D2 mutant $(\boldsymbol{F})$ mice. Insets show magnified images of GPe. Scale bar, $1 \mathrm{~mm}$. G, Quantification of weight gain during the second and third postnatal weeks in ERK:D1 mutant mice compared with ERK ${ }^{-/-}$;ERK2 ${ }^{\mathrm{F} / \mathrm{Fl}}$ littermate controls. ERK:D1 animals show significant deficits in weight gain beginning at P7 and continuing through P19 ( $n=6$ animals/genotype, main effect for genotype $F_{(1,10)}=84.96,{ }^{*} p<0.0001$, Bonferroni post hoc comparison). $\boldsymbol{H}$, Kaplan-Meier survival curve of ERK:D1 (blue line, $n=80$ mice) and ERK:D2 (green line; $n=$ 71 mice) mice compared with ERK1 ${ }^{-/-}$;ERK2 ${ }^{\mathrm{FI} / F \mathrm{I}}$ controls (black line, $n=57$ mice). ERK:D1 mice show a significant reduction in survival ( ${ }^{*} p<0.0001$, post hoc Gehan-Breslow-Wilcoxon test). All data are presented as mean \pm SEM.

MSNs, respectively. Littermate $E r k 1^{-1-} E r k 2^{\text {loxPlloxP }}$ mice were also germline null for ERK1 and were used as controls for all studies unless otherwise noted. Because both D1 and D2 receptors are expressed in other brain regions (Gong et al., 2007), we cannot fully exclude the possibility of nonstriatal contributions to the strong phenotypes that we describe below.

To verify that ERK2 was specifically ablated in D1R-MSNs and D2R-MSNs of ERK:D1 and ERK:D2 animals, respectively, we analyzed the cell-type-specific expression of ERK2 at P21 using immunohistochemistry. To distinguish between MSN sub- types, both the ERK:D1 and ERK:D2 lines were crossed with the D1 ${ }^{\text {tdTomato }}$ reporter mouse line (Ade et al., 2011). Expression of tdTomato red fluorescent protein exclusively in D1R-MSNs allowed us to distinguish between D1R-MSNs (red fluorescence) and D2R-MSNs (no fluorescence). In ERK:D1 animals, only 3\% of D1R-MSNs expressed ERK2 compared with control littermates (Welch-corrected $t_{(2.16)}=84.77, p=0.0001$; Fig. $1 A$ ). We observed a similar reduction in ERK2 expression in D2R-MSNs of ERK:D2 mutant mice (Welch-corrected $t_{(2.95)}=$ $40.64, p=0.0001$; Fig. $1 B$ ). Our findings demonstrate that ERK activity is ablated in distinct MSN populations of ERK:D1 and ERK:D2 mutant mice.

ERK signaling has been implicated previously in cellular growth and maintenance (Cargnello and Roux, 2011). To assess the integrity of the ERK-deficient MSN axonal projections, we crossed ERK:D1 and ERK:D2 mice with the Ai3 reporter line, which conditionally expresses enhanced yellow fluorescent protein in a Credependent manner (Madisen et al., 2010). D1R-MSN projections to the GPi and $\mathrm{SNr}$ appeared intact in ERK:D1 mutant mice compared with littermate controls (Fig. $1 C, D, \mathrm{P} 21)$. Similarly, D2R-MSN projections to the GPe also appeared unaffected in ERK:D2 animals (Fig. 1E,F, P21). Moreover, we assessed MSN subtype survival at P21 by comparing the percentages of D1RMSN and D2R-MSN cells in both ERK:D1 and ERK:D2 mice relative to littermate controls. For ERK:D1 mice ( $n=3$ mice/ genotypes), we did not observe a significant difference in the percentage of D1RMSNs $(53.1 \% \pm 1.38$ for control vs $52.3 \pm$ $0.94 \%$ for ERK:D1, Welch-corrected $\left.t_{(3.52)}=0.51, p=0.64\right)$ or D2R-MSNs $(47.4 \pm 0.69 \%$ for control vs $47.3 \pm 0.57 \%$ for ERK:D1, Welch-corrected $t_{(3.83)}=0.13$, $p=0.90)$ compared with control littermates. Similarly, we did not observe any significant changes in the percentage of D1R-MSNs $(51.6 \pm 0.73 \%$ for control vs $50.6 \pm 2.53 \%$ for ERK:D2, Welch-corrected $\left.t_{(2.34)}=0.37, p=0.75\right)$ or D2R-MSNs $(48.5 \pm 0.73 \%$ for control vs $49.4 \pm 2.53 \%$ for ERK:D2, Welch-corrected $t_{(2.33)}=0.37$, $p=0.74)$ in ERK:D2 mice relative to littermate controls ( $n=3$ mice/genotype). These results suggest that ERK activity is not necessary for the targeting or maintenance of D1RMSN or D2R-MSN projections. However, we cannot exclude modest effects on axon branching or synaptogenesis.

Both ERK:D1 and ERK:D2 mice were generated in the appropriate Mendelian ratios. However, we observed a significant reduction in weight gain between P7 and P19 in ERK:D1 mutants compared with littermate controls (repeated-measures ANOVA; main genotype effect, $F_{(1,5)}=91.90, p=0.0002$; main time effect 
$F_{(6,30)}=494.1, p=0.0001$, time $\times$ genotype interaction: $F_{(6,30)}=$ $59.92, p=0.0001$; Fig. $1 G$ ) and a significant decrease in survival beginning at 3 weeks of age (median age of death $=28 \mathrm{~d}$; GehanBreslow-Wilcoxon survival test: $\chi_{(1)}^{2}=60.72, p=0.0001$; Fig. $1 H)$. In contrast, ERK:D2 mice survived normally compared with littermate controls (Gehan-Breslow-Wilcoxon survival test: $\chi_{(1)}^{2}=0.065, p=0.799$; Fig. $\left.1 H\right)$.

\section{ERK signaling is required for pathway-specific regulation of} locomotor behavior

Previous studies using genetic cell ablation or optogenetic manipulation have shown that D1R-MSN loss or inhibition dramatically reduces locomotor activity (Drago et al., 1998; Kravitz et al., 2010; Durieux et al., 2012), whereas ablation or optogenetic silencing of D2R-MSNs increases locomotion (Durieux et al., 2009; Kravitz et al., 2010). To determine whether ERK signaling is essential for pathway-specific locomotor function, we assessed basal locomotor activity in naive ERK:D1 and ERK:D2 mice using a 30 min open-field assay. Analysis of ERK:D1 mice at P21 showed a significant decrease in activity compared with littermate controls, demonstrating that ERK activity in D1R-MSNs is necessary for facilitating locomotor behavior (Welch-corrected $t_{(10.98)}=3.80, p=$ 0.003; Fig. 2A, $B$ ). However, the rapid decline in health of ERK:D1 mutant mice precluded us from pursuing more detailed analyses of this line because we could not properly control for potential secondary health effects on D1R-MSN functions.

In contrast, ERK:D2 mutant mice showed a significant increase in total distance traveled compared with littermate controls (Welch-corrected $t_{(10.8)}=4.93, p=0.0005$; Fig. 2C,D). To assess potential sexual dimorphism, we also compared open-field activity between male and female ERK:D2 mice, but found no significant differences $(14.2 \mathrm{~m} \pm 2.08$ male vs $15.5 \mathrm{~m} \pm 2.09$ female; post hoc Welch-corrected $t_{(7.5)}=0.42, p=0.68, n=4$ male mice, 6 female mice). To investigate whether ERK:D2 mice eventually acclimate to the testing arena and reduce their basal activity, we also analyzed the mice in a $3 \mathrm{~h}$ open-field assay. Locomotor activity in control animals decreased steadily throughout the trial. In contrast, ERK:D2 mutant mice maintained a high level of activity throughout the $3 \mathrm{~h}$ testing period (repeatedmeasures ANOVA: main genotype effect: $F_{(1,9)}=31.70, p=$ 0.0003 ; time $\times$ genotype interaction: $F_{(17,153)}=4.73, p=0.0001$; Fig. $2 E)$. These results demonstrate that ERK activity is required for the proper function of D2R-MSNs in suppressing locomotor behavior.

\section{Reduced dendritic spine formation and activity-induced gene expression in ERK-deficient D2R-MSNs}

Pharmacological blockade of ERK activity prevents stimulationinduced dendritic spine formation in ex vivo slice systems (Goldin and Segal, 2003; Alonso et al., 2004). However, it is unclear whether ERK is required for spinogenesis during normal striatal development. To determine whether dendritic spines are altered in ERK-deficient D2R-MSNs, we labeled sparse populations of MSNs by injecting an AAV8-CAG-GFP virus unilaterally into the striatum of ERK:D2 and littermate control P1 neonatal animals. We then killed the mice at P21, a period during which active synaptogenesis is occurring in the striatum (Tepper et al., 1998; Goldin and Segal, 2003; Alonso et al., 2004; Kozorovitskiy et al., 2012). AAV8-CAG-GFP brightly labels the entire MSN, including dendritic spines, which were then imaged using 3D confocal microscopy. To distinguish between D1R-MSN and D2R-MSNs, we backcrossed the ERK:D2 line with the $\mathrm{D} 1^{\text {tdTomato }}\left(\mathrm{D} 1^{\mathrm{tdT}}\right.$ )

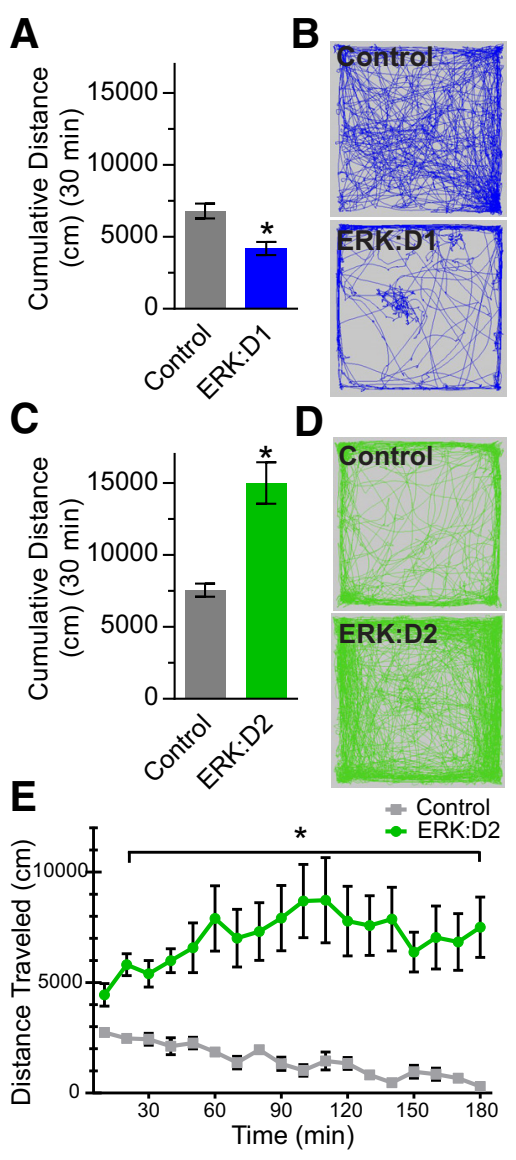

Figure 2. ERK signaling is required for pathway-specific regulation of locomotor behavior A, Quantification of total distance traveled in a 30 min testing period by ERK:D1 (blue bar) and paired littermate control (gray bar) mice at P21. ERK:D1 animals show a significant reduction in locomotor activity ( ${ }^{*} p<0.01, n=10$ mice/genotype). $\boldsymbol{B}$, Representative recordings of total distance traveled ( $30 \mathrm{~min}$ ) in control and ERK:D1 animals. C, Quantification of total distance traveled in a 30 min testing period by ERK:D2 mutant mice (green bar) and paired littermate controls (gray bar). ERK:D2 mutants show significantly more locomotor activity than controls $\left({ }^{*} p<0.001, n=10 \mathrm{mice} /\right.$ genotype). $\boldsymbol{D}$, Representative tracks of cumulative open-field activity for control and ERK:D2 mutant mice. $E$, Three hour open-field analysis of ERK:D2 mice and controls. Shown is total distance traveled as a function of time. ERK:D2 mutant mice (green trace) showed significantly increased movement throughout the entire $3 \mathrm{~h}$ testing period compared with control animals (gray trace), which steadily reduce activity throughout the trial $\left({ }^{*} p<0.001 ; n=10\right.$ mice/genotype). All data are presented as mean \pm SEM.

reporter line, which expresses tdTomato red fluorescent protein exclusively in D1R-MSNs (Ade et al., 2011). Therefore, all cells that coexpressed GFP and tdTomato were identified as D1RMSNs, whereas cells that expressed GFP only were identified as D2R-MSNs (Fig. 3A).

At $\mathrm{P} 21$, a significant reduction in the density of spines was observed along dendrites of D2R-MSNs in ERK:D2 mice compared with littermate controls (Welch-corrected $t_{(2.148)}=6.190$, $p=0.0211$; Fig. $3 B, C)$. The effect was more prominent for thinner spines normally associated with plasticity than for thicker, broader spines. Interestingly, we did not observe a significant change in spine density along dendrites of D1R-MSNs in ERK:D2 animals (Welchcorrected $t_{(2.444)}=0.5122, p=0.6511$; Fig. $\left.3 B, C\right)$.

In addition to changes in dendritic spines, we also observed a reduction in soma size in ERK-deficient MSNs. Quantitative analysis demonstrated that D2R-MSNs showed a significant reduction in somal area in ERK:D2 animals compared with littermate control mice (control $=138.1 \mu \mathrm{m}^{2} \pm 1.855$; ERK:D2 $=$ $113.6 \mu \mathrm{m}^{2} \pm 2.034 ;$ Welch-corrected $t_{(5.95)}=8.893, p=0.0001$; 


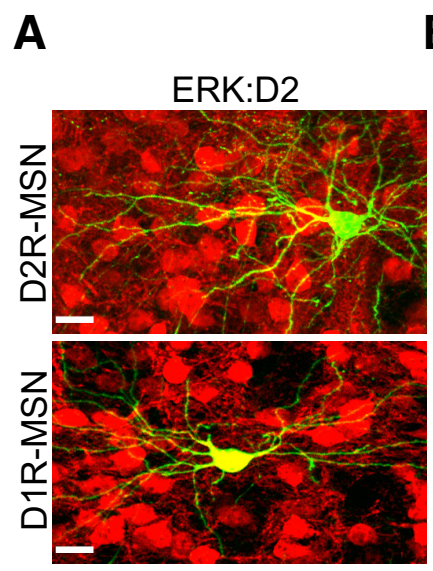

D

\begin{tabular}{|c|c|c|}
\hline \multicolumn{3}{|c}{ Immediate Early Genes } \\
\hline Gene & Anova p-Value & $\begin{array}{c}\text { Fold Change } \\
\text { (Compared to Control) }\end{array}$ \\
\hline Egr1 & 0.005808 & -2.1 \\
\hline Egr2 & 0.000953 & -1.96 \\
\hline Fos & 0.079076 & -1.91 \\
\hline Fosl2 & 0.032868 & -1.78 \\
\hline Egr3 & 0.069367 & -1.74 \\
\hline Egr4 & 0.002845 & -1.51 \\
\hline Fosb & 0.067583 & -1.38 \\
\hline KIf10 & 0.052887 & -1.37 \\
\hline Srf & 0.011213 & -1.36 \\
\hline
\end{tabular}

B
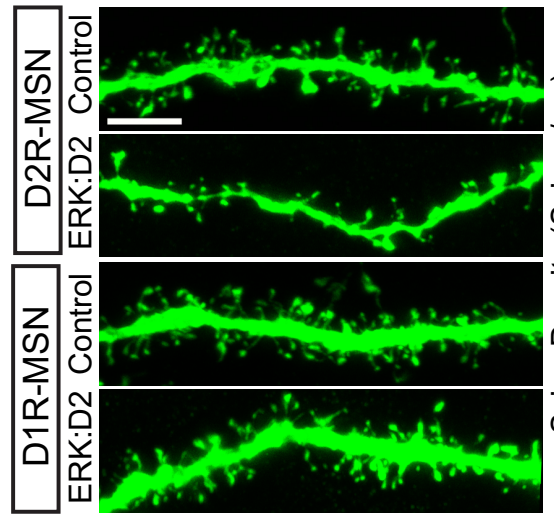

E

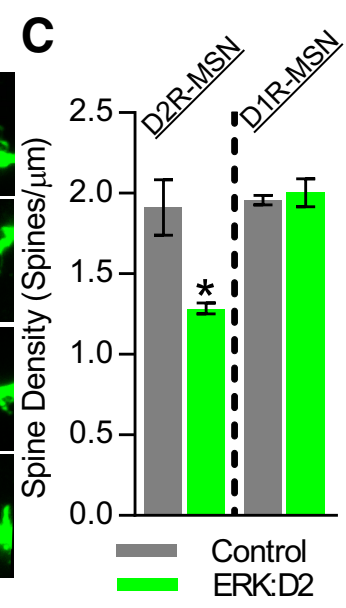

Synaptic Plasticity Associated Genes

\begin{tabular}{|c|c|c|}
\hline Gene & Anova p-Value & $\begin{array}{c}\text { Fold Change } \\
\text { (Compared to Control) }\end{array}$ \\
\hline Arc & 0.011947 & -2.85 \\
\hline Nr4a1 & 0.00621 & -2.44 \\
\hline Rgs2 & 0.001251 & -1.72 \\
\hline Homer1 & 0.009969 & -1.42 \\
\hline Nptx2 & 0.006279 & -1.36 \\
\hline
\end{tabular}

$\mathrm{p}<0.05$

Figure 3. ERK signaling is required for proper spinogenesis and expression of synaptic plasticity genes. A, Representative images of D1R-MSN and D2R-MSNs labeled with AAV8-CAG-GFP virus (green). D1R-MSNs are identified by their expression of the D1 ${ }^{\text {tdTomato }}$ transgene (red) and D2R-MSNs are D1 ${ }^{\text {tdTomato }}$ negative. GFP-expressing D2R-MSNs appear green, whereas GFP-expressing D1R-MSNs appear yellow. Scale bar, $20 \mu \mathrm{m}$. B, AAV8-CAG-GFP efficiently labels MSN dendritic spines. D2R-MSNs in ERK:D2 mutant mice show a significant reduction in spine density compared with littermate controls. In contrast, there is no difference in spine density on D1R-MSNs between mutant and control animals. Scale bar, $5 \mu \mathrm{m}$. $\boldsymbol{C}, \mathrm{Quantification}$ of mean spine density shows a reduction in dendritic spines in D2R-MSNs ( ${ }^{*} p<0.05 ; n=3$ mice/genotype, 15 dendrites/mouse), but not D1R-MSNs ( $p<0.65 ; n=3$ mice/genotype, 15 dendrites/mouse), in ERK:D2 mutant mice compared with littermate controls. $\boldsymbol{D}, \boldsymbol{E}$, Microarray analysis of P17 striatum ( $n=3$ male mice/genotype) showing dramatic reduction in the expression of activity-induced immediate early genes (D) and genes associated with synaptic plasticity $(\boldsymbol{E}){ }^{*} p<0.05$.

$n=4$ mice/genotype, 5 cells/mouse). These results are consistent with previous reports of reduced soma diameter in D2R-MSNs of conditional BDNF-TrkB knock-out mice (Li et al., 2012).

Defects in spinogenesis might be expected to lead to reductions in activity-regulated transcripts and in abnormal physiological function (see below). To investigate the transcriptional changes that occur in ERK-deleted D2R-MSNs during the period of active striatal synaptogenesis, we performed microarray analysis on striatal punches from littermate control and ERK:D2 mice at P17 (Tepper et al., 1998; Goldin and Segal, 2003; Kozorovitskiy et al., 2012). We observed a significant reduction in the expression of a number of critical immediate early genes (IEGs); Egr1, Egr2, Egr4, Fosl2, and Srf levels were all significantly reduced in ERK:D2 mice (Fig. 3D). These reductions are consistent with the idea that ERK-deficient D2-MSNs are severely impaired in their ability to respond to presynaptic stimuli (Okuno, 2011).

We also identified a number of genes associated with synapse formation and plasticity that show significantly downregulated expression in ERK:D2 mutant mice (Fig. 3E). We observed significantly reduced expression of the postsynaptic genes Arc, Homer1, and Nptx2; the G-protein signaling regulator Rgs2; and the transcriptional activator Nr4a1 (West and Greenberg, 2011; Chen et al., 2014). Together, our results related to spinogenesis and activityregulated gene expression suggest that ERK activity is necessary for proper synaptic function and downstream signaling events.
Reduced synaptic drive and intrinsic excitability in ERK-deleted D2R-MSNs

Our findings that ERK:D2 mice have increased locomotor activity logically raise the question of whether electrophysiological properties of D2R-MSNs may also be affected. To test this, patchclamp electrophysiological recordings were obtained ex vivo to identify the strength of excitatory and inhibitory synaptic input to D2R-MSNs in ERK:D2 and control littermates (Fig. 4A). Recordings of mEPSCs (Fig. $4 B, C$ ) revealed a reduction in the frequency $\left(t_{(16)}=3.32 ; p=0.004\right)$, but not amplitude $\left(t_{(16)}=1.74\right.$; $p=0.101$ ), of D2R-MSN mEPSCs in ERK:D2 mutant (black trace) versus control mice (gray trace). Recordings of mIPSCs (Fig. $4 D, E)$ revealed a reduction in both frequency $\left(t_{(15)}=3.13\right.$; $p=0.007)$ and amplitude $\left(t_{(15)}=3.10 ; p=0.007\right)$ of D2R-MSN mIPSCs in ERK:D2 mice (black trace) versus control mice (gray trace). Together, these data reveal a reduction in both excitatory and inhibitory synaptic drive onto D2R-MSNs in ERK:D2 mice.

Next, we obtained ex vivo patch-clamp electrophysiological recordings to identify the strength of excitatory and inhibitory synaptic input to D1R-MSNs (Fig. 4F) in ERK:D2 mutant and control animals. Recordings of mEPSCs (Fig. 4G,H) revealed no change in the frequency $\left(t_{(13)}=1.43 ; p=0.178\right)$ or amplitude $\left(t_{(13)}\right.$ $=0.95 ; p=0.359$ ) of D1R-MSN mEPSCs in ERK:D2 mice (black trace) versus control mice (red trace). Similarly, recordings of mIPSCs (Fig. $4 I, J)$ revealed no change in the frequency $\left(t_{(13)}=\right.$ 
A

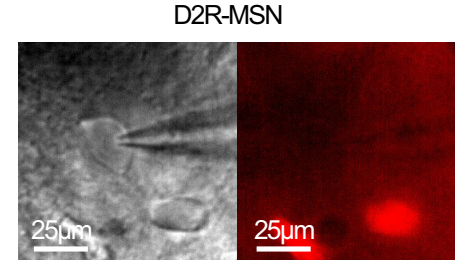

B

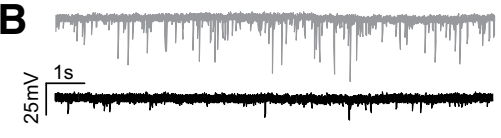

\section{C}

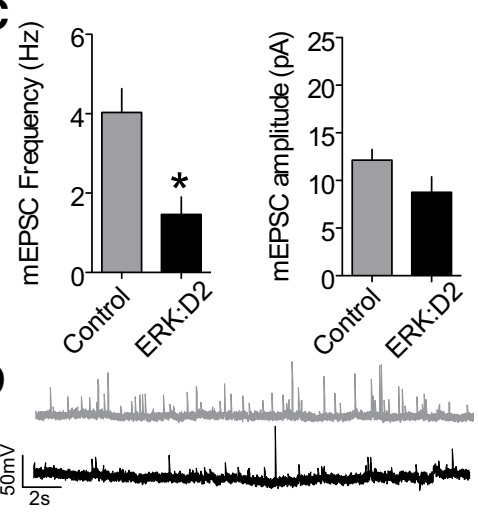

E
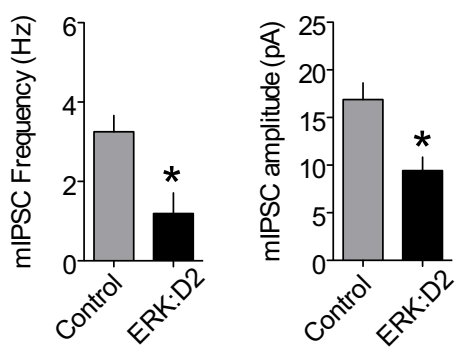

K

D2R-MSN

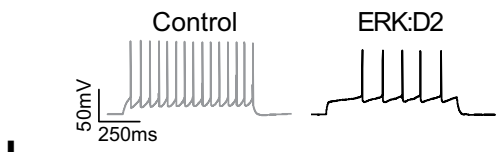

L

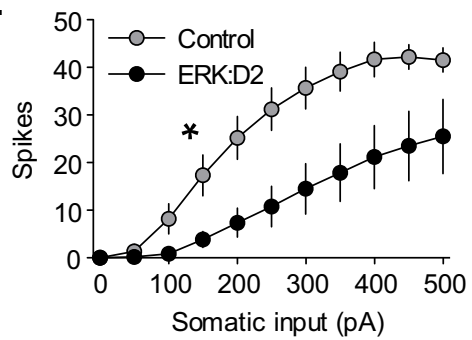

$\mathbf{F}$

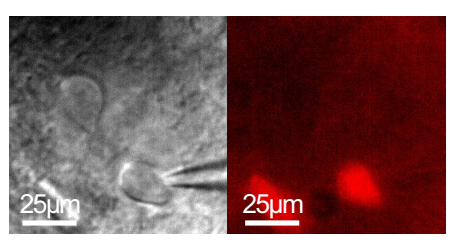

G

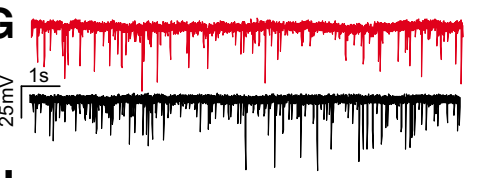

$\mathrm{H}$

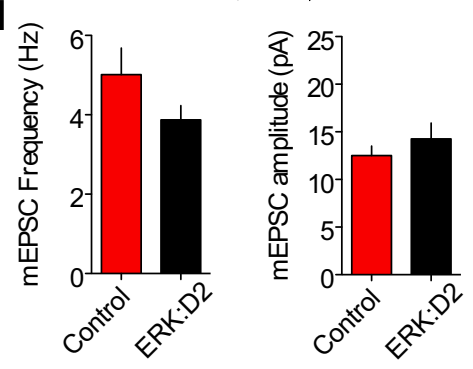

I

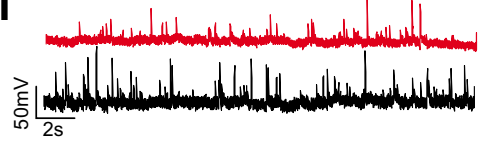

J

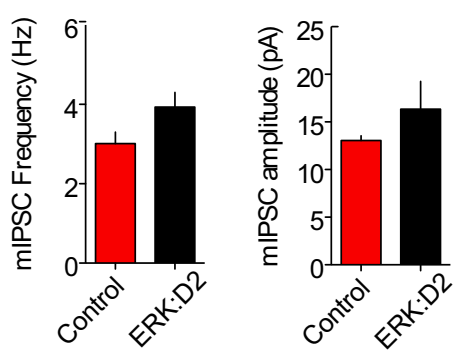

M

D1R-MSN

N

$\mathbf{N}$
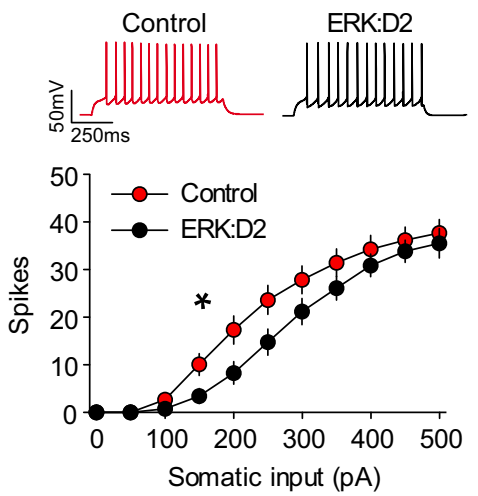

Figure 4. Markedly reduced excitability of ERK-deleted D2R-MSNs. $\boldsymbol{A}$, Image of pipette recording from a D2R-MSN negative for D1 ${ }^{\text {tdTomato }}$ (red). $\boldsymbol{B}$, Representative mEPSC recordings of D2R-MSNs from control (gray) and ERK:D2 mutant (black) mice. C, Summary of mEPSC frequencies and amplitudes from control (gray; $n=3$ mice, $n=10$ neurons) and ERK:D2 mutant (black; $n=3$ mice, $n=8$ neurons) D2R-MSNs. mEPSC frequency is significantly reduced in ERK:D2 mutant D2R-MSNs $\left({ }^{*} p<0.01\right)$, whereas $m E P S C$ amplitude is unchanged. $D$, Representative mIPSC recordings of D2R-MSNs from control (gray) and ERK:D2 mutant (black) mice. $\boldsymbol{E}$, Summary of mIPSC frequencies and amplitudes from control (gray; $n=3$ mice; $n=10$ neurons) and ERK:D2 mutant (black; $n=3$ mice; $n=7$ neurons) D2R-MSNs. Both mIPSC frequency and amplitude are reduced significantly in ERK:D2 mutant D2-MSNs ( $\left.{ }^{*} p<0.01\right)$. $\boldsymbol{F}$, Representative image of recording pipette in a D1 ${ }^{\text {tdTomato }}$-positive (red) D1R-MSN. G, Representative mEPSC recordings of D1R-MSNs from control (red) and ERK:D2 mutant (black) mice. $\boldsymbol{H}$, Summary of mEPSC frequencies and amplitudes from control (red; $n=3$ mice; $n=8$ neurons) and ERK:D2 mutant (black; $n=3$ mice; $n=7$ neurons) D1R-MSNs There is no significant change in mEPSC frequency or amplitude in ERK:D2 mutant D1R-MSNs compared with control. $I$, Representative mIPSC recordings of D1R-MSNs from control (red) and ERK:D2 mutant (black) mice. J, Summary of mIPSC

1.97; $p=0.070)$ or amplitude $\left(t_{(13)}=\right.$ $1.18 ; p=0.260)$ of D1R-MSN mIPSCs in ERK:D2 mice (black trace) versus control mice (red trace). These results suggest that loss of ERK activity in D2R-MSNs does not alter synaptic drive significantly in D1R-MSNs.

In addition to changes in synaptic activity, alterations in the intrinsic excitability of neurons can lead to modifications in the activity of neural networks. Therefore, we evaluated the intrinsic excitability of D2R-MSNs in ERK:D2 and control mice. Overall, we found that the intrinsic excitability of D2R-MSNs in ERK:D2 mice (black trace) was reduced compared with control mice (gray trace) (Fig. $4 K, L$ ). Two-way ANOVA revealed a significant interaction $\left(F_{(10,170)}=4.417, p=0.0001\right)$ and planned comparisons revealed that the maximum number of action potentials for any sweep was lower in neurons from ERK:D2 mice versus control mice (Table 1). Furthermore, this reduction in action potential frequency in ERK:D2 mice was likely attributable to a reduced capacity to initiate action potentials because both rheobase and action potential amplitude were reduced (Table 1). Finally, we performed intrinsic excitability recordings in D1R-MSNs from ERK:D2 and control mice. Overall, we found that the intrinsic excitability of D1R-MSNs in ERK:D2 mice (black trace) was slightly reduced compared with that of control mice (red trace) (Fig. 4M,N). Two-way ANOVA revealed a significant interaction $\left(F_{(10,160)}=2.93 ; p=0.002\right)$, although planned comparisons revealed no differences in the maximum number of action potentials for any sweep, rheobase, or action potential amplitude (Table 1). These

\section{$\leftarrow$}

frequencies and amplitudes from control (red; $n=3$ mice; $n=8$ neurons) and ERK:D2 mutant (black; $n=3$ mice; $n=7$ neurons) D1R-MSNs. There is no significant difference between ERK:D2 mutant D1R-MSNs and control MSNs. $\boldsymbol{K}$, Representative traces of whole-cell patch-clamp recordings from D2R-MSNs in control (gray) and ERK:D2 mutant (black) mice. $\boldsymbol{L}$, Relationship between elicited action potential responses and somatic current injection in D2R-MSNs of control (gray; $n=3$ mice; $n=9$ neurons) and ERK:D2 mutant (black; $n=3$ mice; $n=10$ neurons) mice. D2R-MSNs from ERK:D2 mutant mice have a significantly reduced capacity to elicit action potentials $\left({ }^{*} p<0.001\right)$. $\boldsymbol{M}$, Representative traces of whole-cell patch-clamp recordings from D1R-MSNs in control (red) and ERK:D2 mutant (black) mice. $\boldsymbol{N}$, Relationship between elicited action potential responses and somatic current injection in D1R-MSNs of control (red; $n=3$ mice; $n=9$ neurons) and ERK:D2 mutant (black; $n=3$ mice; $n=9$ neurons) mice. Intrinsic excitability in D1R-MSNs of ERK:D2 mutant mice was slightly, but significantly, reduced compared with controls $\left({ }^{*} p<0.01\right)$. 
Table 1. Membrane and action potential properties of ERK:D2 MSNs

\begin{tabular}{|c|c|c|c|c|c|c|c|}
\hline Group & $\operatorname{IR}(M \Omega)$ & $\mathrm{RMP}(\mathrm{mV})$ & Rheo (pA) & Thresh (mV) & Amp (mV) & H.W. (ms) & MaxAPs \\
\hline D2R Control & $126 \pm 19$ & $-79.6 \pm 2.7$ & $161 \pm 20$ & $-38.8 \pm 1.3$ & $72.0 \pm 3.2$ & $0.87 \pm 0.07$ & $45.1 \pm 3.3$ \\
\hline D2R Erk:D2 & $115 \pm 15$ & $-76.2 \pm 4.7$ & $315 \pm 68^{*}$ & $-29.4 \pm 4.5$ & $52.8 \pm 7.7^{*}$ & $0.87 \pm 0.10$ & $25.6 \pm 7.8^{*}$ \\
\hline D1R Control & $87 \pm 12$ & $-85.6 \pm 2.0$ & $204 \pm 16$ & $-38.5 \pm 2.2$ & $73.1 \pm 4.6$ & $0.87 \pm 0.06$ & $37.7 \pm 2.9$ \\
\hline D1R Erk:D2 & $73 \pm 6$ & $-76.9 \pm 4.6$ & $252 \pm 18$ & $-33.9 \pm 2.1$ & $68.3 \pm 4.4$ & $0.87 \pm 0.05$ & $36.7 \pm 2.4$ \\
\hline
\end{tabular}

Basic membrane properties and action potential properties in D2R-MSNs and D1R-MSNs recorded during intrinsic excitability experiments.

IR, Input resistance; RMP, resting membrane potential; Rheo, rheobase; Thresh, action potential threshold; Amp, action potential amplitude; H.W., half-width; MaxAPs, maximum number of action potentials for any current step. ${ }^{*} p<0.05$ versus control neurons.

data demonstrate that ERK-deficient D2R-MSNs have a significantly reduced capacity to fire action potentials.

\section{Activity-regulated gene expression is strongly suppressed in ERK-deleted D2R-MSNs}

In D2R-MSNs, dopamine binding to $\mathrm{D} 2 \mathrm{R} / \mathrm{G}_{\alpha \mathrm{i}}$-coupled receptors represses neuronal excitability (Surmeier et al., 2007), whereas D2R antagonists, including haloperidol, derepress the cell and allow it to respond to excitatory input (Bonito-Oliva et al., 2011). In mice, haloperidol administration has been shown to induce catalepsy (Sanberg, 1980; Farde et al., 1992), an effect associated with increased phosphorylated ERK activity in D2R-MSNs (Bertran-Gonzalez et al., 2008). To determine whether D2RMSN-specific ERK activity is necessary for cataleptic behavior, we administered haloperidol ( $1 \mathrm{mg} / \mathrm{kg}$, i.p.) or vehicle to adult ERK:D2 mutants and littermate controls and tested for cataleptic response $1 \mathrm{~h}$ after administration using the horizontal bar test (Fig. 5A). Two-way ANOVA revealed a significant difference between genotypes $\left(F_{(1,24)}=149.0, p=0.0001\right)$, treatment $\left(F_{(1,24)}=\right.$ $118.9, p=0.0001)$, and a genotype $\times$ treatment interaction $\left(F_{(1,24)}=114.3, p=0.0001\right)$. Haloperidol administration led to an extended cataleptic freezing response in control mice compared with vehicle-treated controls (vehicle control vs haloperidol control Tukey's post hoc adjusted: $p=0.0001$; Fig. $5 B$ ). Strikingly, haloperidol-treated ERK:D2 littermates were insensitive to these cataleptic effects (haloperidol control vs haloperidol ERK:D2 Tukey's post hoc adjusted: $p=0.0001$; Fig. $5 B$ ). These findings demonstrate that ERK activity in D2R-MSNs is necessary for the induction of haloperidol-induced catalepsy in mice.

In addition to cataleptic behavior, haloperidol administration has also been demonstrated to strongly enhance activity-regulated gene expression in the striatum (Robertson et al., 1992). c-FOS is a well documented activity-induced gene and has been shown to be upregulated selectively in D2R-MSNs after acute haloperidol administration (Bertran-Gonzalez et al., 2008). We therefore analyzed cell-specific c-FOS expression in ERK-deleted and control D2R-MSNs after haloperidol or vehicle administration. To distinguish between D1R-MSN and D2R-MSNs, we again used the $\mathrm{D} 1^{\text {tdT }}$ mouse line to identify D1R-MSNs (see above). We also colabeled with the ubiquitous MSN marker CTIP2 to exclude non-MSN cells from analysis (Arlotta et al., 2008). CTIP2positive neurons that expressed tdTomato were identified as D1RMSNs, whereas CTIP2-positive, tdTomato-negative cells were identified as D2R-MSNs. Two-way ANOVA revealed significant differences between genotype $\left(F_{(1,8)}=1128.7, p=0.0001\right)$, treatment $\left(F_{(1,8)}=1334.9, p=0.0001\right)$, and a genotype $\times$ treatment interaction $\left(F_{(1,8)}=5220.2, p=0.0001\right)$. In control animals, haloperidol treatment increased the percentage of D2R-MSNs expressing c-FOS significantly compared with vehicle treatment (Tukey's post hoc adjusted: $p=0.0001$; Fig. $5 C, E$ ). Figure $5 C$ shows numerous c-FOS-expressing cells in a haloperidol-treated control animal (top inset shows high magnification of all three labels with yellow arrows indicating D2R-MSNs expressing c-FOS; bottom inset shows c-FOS only). Strikingly, haloperidol administration failed to induce c-FOS expression in D2R-MSNs from ERK:D2 mutants because we found virtually no c-FOS labeling in these mice (Tukey's post hoc adjusted: $p=0.0001$; Fig. $5 D, E$ ). We did not observe any changes in c-FOS expression in D1R-MSNs in any sample group (Fig. 5F). These findings demonstrate that activity-induced expression of c-FOS is almost completely abolished in ERK-deficient D2R-MSNs.

Our observation that activity-induced c-FOS expression is decreased in ERK:D2 mice led us to investigate whether activityregulated synaptic plasticity genes were similarly affected. Therefore, we analyzed expression of the activity-induced synaptic cytoskeletal protein ARC in response to haloperidol or vehicle administration in ERK:D2 mice and littermate controls. Two-way ANOVA revealed significant differences between genotype $\left(F_{(1,8)}=\right.$ $129.8, p=0.0001)$, treatment $\left(F_{(1,8)}=84.05, p=0.0001\right)$, and a genotype $\times$ treatment interaction $\left(F_{(1,8)}=80.89, p=0.0001\right)$. In control animals, haloperidol treatment greatly increased the percentage of D2R-MSNs expressing ARC compared with vehicle treatment (Tukey's post hoc adjusted: $p=0.0001$; Fig. 5G,I). Figure $5 G$ shows numerous ARC-expressing cells in a haloperidol-treated control animal (top inset shows high magnification of all three labels with yellow arrows indicating D2R-MSNs expressing ARC; bottom inset shows the ARC label only). In contrast, we observed minimal ARC expression in haloperidol-treated ERK:D2 mice (Tukey's post hoc adjusted: haloperidol-treated ERK:D2 vs control, $p=0.0001$; Fig. $5 H, I$, arrows in the top and bottom insets show ARC-deficient D2R-MSNs; green cells in the bottom inset are D1R-MSNs expressing ARC).

Interestingly, we found that there is significantly increased expression of ARC in D1R-MSNs of ERK:D2 mice in both haloperidol- and vehicle-treated mutants compared with littermate controls receiving the same treatment (Fig. 5J). Two-way ANOVA revealed significant differences between genotype $\left(F_{(1,8)}=\right.$ $129.8, p=0.0001)$, treatment $\left(F_{(1,8)}=84.05, p=0.0001\right)$, and a genotype $\times$ treatment interaction $\left(F_{(1,8)}=80.89, p=0.0001\right)$. Although D1R-MSNs did not show hyperexcitability in acute slices from ERK:D2 mice, it remains plausible that the network-level homeostatic changes in D1R-MSN activity might account for this result.

\section{Discordant effects of ERK deletion between the D2-Cre and Adora2-Cre line}

In the D2-Cre line, Cre is expressed in a population of striatal cholinergic interneurons in addition to D2R-MSNs (Kravitz et al., 2010; Durieux et al., 2011). Therefore, we performed similar experiments in the Adora2a-Cre line (A2a-Cre), which targets D2R-MSNs but not cholinergic interneurons (Durieux et al., 2009). Surprisingly, we found that ERK:A2a mutant mice did not recapitulate the open-field hyperlocomotor phenotype observed in ERK:D2 mice. Total basal locomotor activity was unchanged 
A
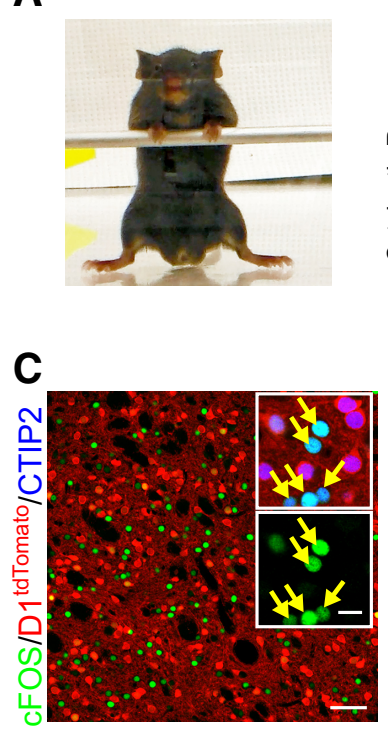

E
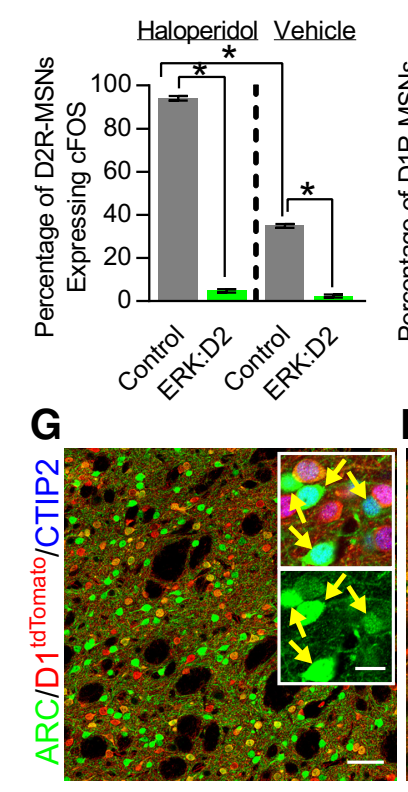

I

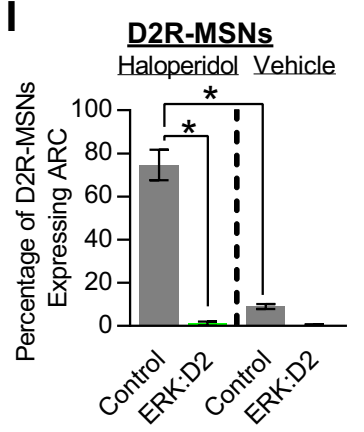

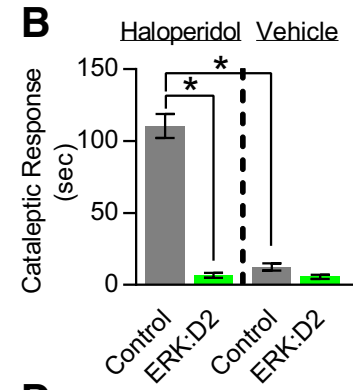

D

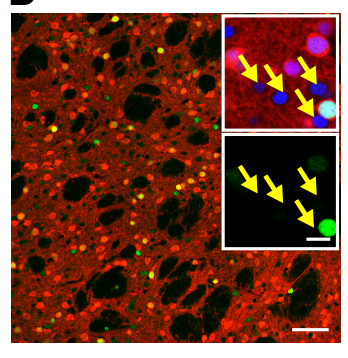

$\mathbf{F}$

D1R-MSNs

Haloperidol Vehicle

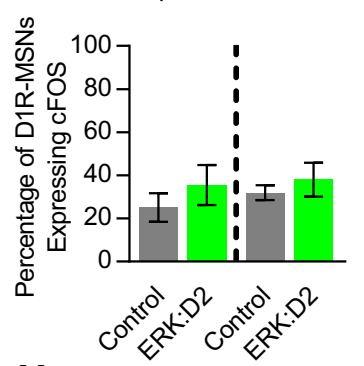

H

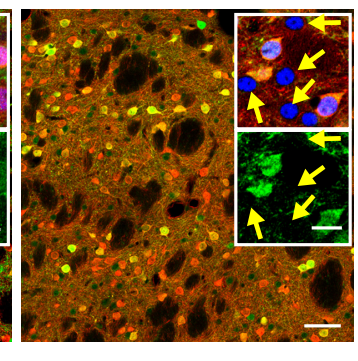

$\mathbf{J}$

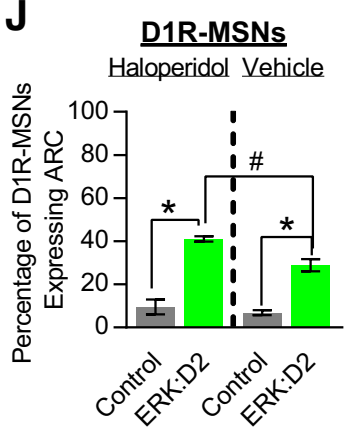

Figure 5. Activity-regulated gene expression is strongly suppressed in ERK-deleted D2RMSNs. A, Representative image of cataleptic response to haloperidol using horizontal bar test. $\boldsymbol{B}$, Quantification of cataleptic response (freezing) to haloperidol $(1 \mathrm{mg} / \mathrm{kg}$ ) or vehicle in littermate control and ERK:D2 mutant mice. Control mice exhibit a robust cataleptic response to haloperidol compared with vehicle-treated controls $\left({ }^{*} p=0.001, n=7\right.$ mice/genotype/condition). The cataleptic response is effectively abolished in the mutant mice $\left({ }^{*} p=0.001\right.$, haloperidol-treated ERK:D2 vs haloperidol treated control; $n=7$ mice/condition). Vehicletreated mice show no cataleptic response ( $n=7$ mice per genotype per treatment).

between ERK:A2a and littermate control mice (Welch-corrected $t_{(10.24)}=0.717, p=0.489$; Fig. $6 A$ ). Likewise, the total locomotor activity profile over the entire $1 \mathrm{~h}$ test session did not differ significantly between ERK:A2a and control animals (repeatedmeasures ANOVA; no main genotype effect, $F_{(1,6)}=1.137, p=$ 0.327 ; no time $\times$ genotype interaction: $F_{(5,30)}=0.127, p=0.985$; Fig. 6B).

We next investigated whether ERK:A2a mutant mice also differed in their response to haloperidol. We first tested these animals for haloperidol-induced catalepsy. Interestingly, ERK:A2a mutants responded similarly to ERK:D2 mutant mice, showing a significantly decreased cataleptic response to haloperidol administration compared with haloperidol-treated controls (Welchcorrected $t_{(6.86)}=5.73, p=0.0008$; Fig. $6 C$ ). Next, we sought to determine whether haloperidol-induced changes in the expression of activity induced genes c-FOS and ARC in ERK:A2a mutants. Consistent with our findings in ERK:D2 mutants, there is a significant reduction in c-FOS-expressing D2R-MSNs in ERK: A2a mutant mice in response to haloperidol (Welch-corrected $t_{(3.61)}=12.65, p=0.0004$; Fig. $\left.6 D-F\right)$. Similarly, ARC expression in D2R-MSNs is almost abolished in ERK:A2a mutant mice after haloperidol administration (Welch-corrected $t_{(3.24)}=4.21, p=$ 0.021; Fig. 6G-I). Therefore, evidence from two independent lines demonstrates that ERK is essential to the regulation of activityinduced gene expression in D2R-MSNs.

\section{Temporal delay in A2a-Cre mediated ERK deletion}

To determine why ERK:D2 and ERK:A2a may differ in their basal locomotor activities, we first verified that ERK2 expression was ablated in D2R-MSNs of ERK:A2a mice. Unexpectedly, we found that a large proportion of D2R-MSNs expressed ERK2 protein at P21 (Fig. 7A). At this stage, $>40 \%$ of D2R-MSNs (45.16 \pm $3.34 \%$ ) maintained ERK2 expression (Fig. 7B). We repeated the analysis at P28 and observed a decrease in ERK2-positive D2RMSNs; however, $\sim 20 \%(16.89 \pm 3.91 \%)$ of D2R-MSNs still expressed ERK2 protein at this age (Fig. $7 B$ ). In contrast, ERK2 expression was effectively lost at P21 in ERK:D2 D2R-MSNs (Fig. $1 D)$. These findings suggest that the A2a-Cre mouse line shows temporally delayed elimination of ERK activity in D2R-MSNs compared with the D2-Cre mouse line.

The discrepancy between our ERK:D2 and ERK:A2a findings suggests a potential spatiotemporal incongruity in Cre expression between the A2a-BAC and Drd2-BAC lines. To determine whether the Cre transgene is expressed effectively in all D2R-MSNs in the A2a line, we first backcrossed these mice with Ai9 Cre-dependent re-

C, D, C-FOS (green) expression in control and ERK:D2 mutant striatum $1 \mathrm{~h}$ after haloperidol administration. CTIP2 (blue) identifies all MSNs; D1 ${ }^{\text {tdTomato }}$ (red) identifies the D1R-MSN subpopulation. All D2R-MSNs are CTIP2(+);tdTomato(-). Insets are magnified images showing all three labels (top) and c-FOS only (bottom) demonstrating that c-FOS is strongly upregulated in D2R-MSNs (yellow arrows) in control (C) but not ERK:D2 animals (D). $\boldsymbol{E}$, Quantification of MSN-specific c-FOS expression after haloperidol $(1 \mathrm{mg} / \mathrm{kg})$ or vehicle administration $\left({ }^{*} p<\right.$ $0.001 ; n=3$ mice/genotype; $200-250$ cells/mouse). $\boldsymbol{F}$, No changes in c-FOS expression are observed in D1R-MSNs in either control or ERK:D2 mutant animals. ( $n=3$ animals/genotype, $200-250$ cells/animal). $\mathbf{G}, \boldsymbol{H}$, ARC (green) expression in control and ERK:D2 mutant striatum $1 \mathrm{~h}$ after haloperidol administration. CTIP2 (blue) identifies all MSNs; D1 ${ }^{\text {tdomato }}$ (red) identifies the D1R-MSN subpopulation. All D2R-MSNs are CTIP2(+);tdTomato(-). Insets are magnified images demonstrating that ARC is upregulated in D2R-MSNs (yellow arrows) in control $(\boldsymbol{G})$ but not ERK:D2 animals $(\boldsymbol{H})$. $\boldsymbol{I}$, Quantification of D2R-MSN-specific ARC expression after haloperidol (1 mg/kg) or vehicle administration ( ${ }^{*} p<0.001 ; n=3$ mice/genotype; $200-250$ cells/ mouse). J, D1R-MSNs in ERK:D2 mutant mice express significantly more ARC compared with controls regardless of treatment ( $\# p<0.05,{ }^{*} p<0.001 ; n=3$ mice/genotype; $200-250$ cells/mouse). All data are presented as mean \pm SEM. Scale bar, $50 \mu \mathrm{m}$; inset, $10 \mu \mathrm{m}$. 
A

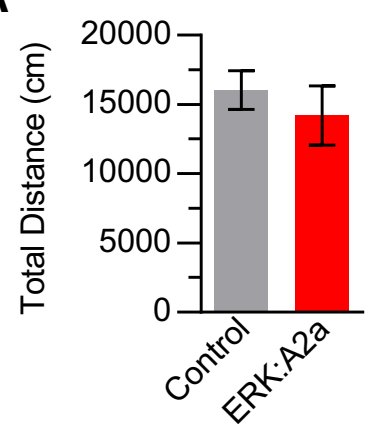

B

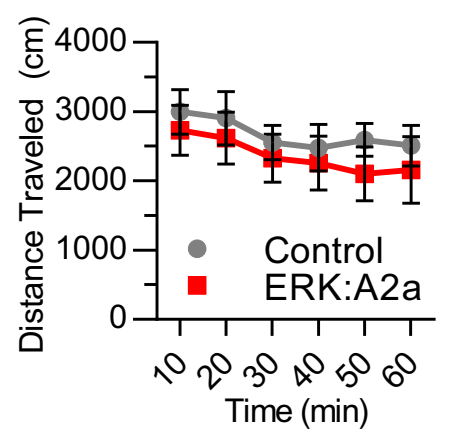

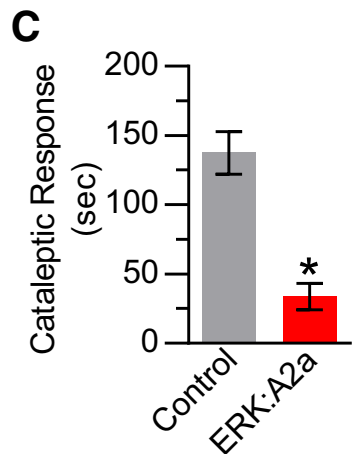

E $\quad$ ERK:A2a

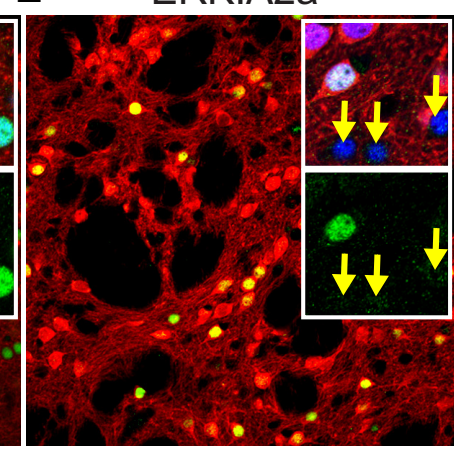

$\mathbf{F}$

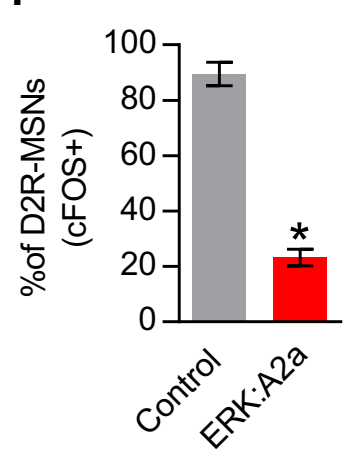

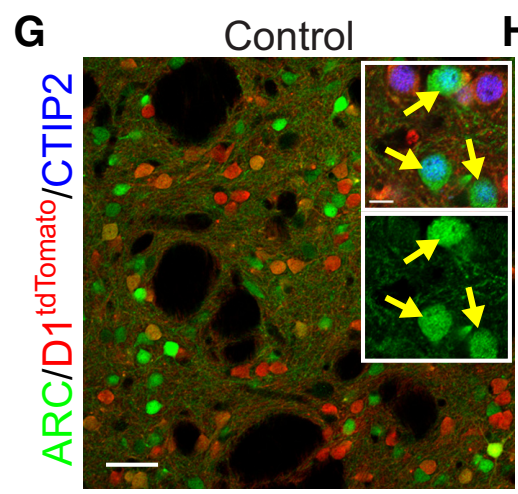
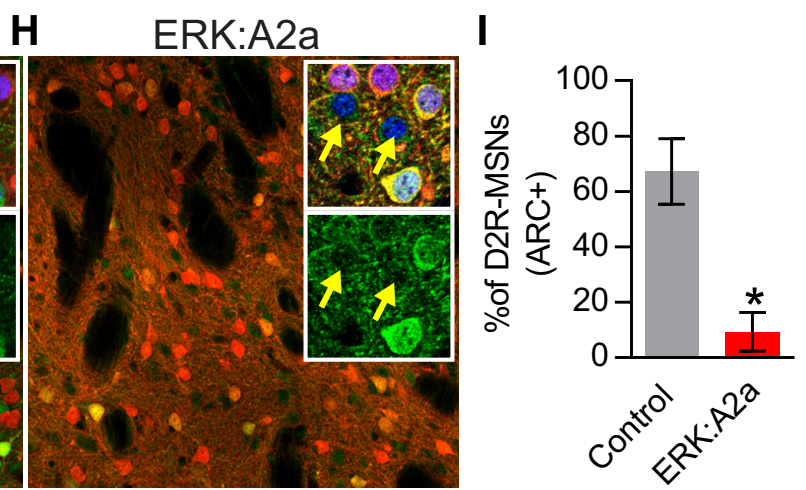

Figure 6. Basal and haloperidol-induced behavioral and gene expression changes in ERK:A2a mice. $A, B$, Open-field locomotor testing of ERK:A2a and control mice ( $n=7$ animals/genotype). $\boldsymbol{A}$, There is no significant difference in cumulative distance traveled (1 $\mathrm{h}$ test) between ERK:A2a mutant and control littermates. $\boldsymbol{B}$, Total distance traveled as a function of time. No differences are observed between mutant and control animals. C, Cataleptic response $1 \mathrm{~h}$ after haloperidol administration (1 mg/kg). ERK:A2a mutant mice have a significantly reduced cataleptic response compared with littermate controls $\left({ }^{*} p<0.001 ; n=6\right.$ mice/genotype). $\boldsymbol{D}, \boldsymbol{E}$, Immunohistochemical labeling of activity-induced gene expression $1 \mathrm{~h}$ after haloperidol administration. All MSNs are

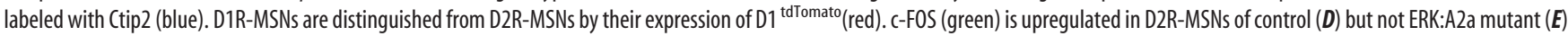
mice. Insets show higher magnification of all three labels (top) and c-FOS only (bottom). D2R-MSNs are indicated by yellow arrows. $F$, Quantitative analysis showing a significant reduction in the percentage of D2R-MSNs expressing c-FOS in ERK:A2a mutant animals compared with control animals ( ${ }^{*} p<0.001 ; n=3$ mice/genotype; $200-250$ cells/mouse). $\boldsymbol{G}, \boldsymbol{H}$, ARC (green) is upregulated in D2R-MSNs (yellow arrows) in control (G) but not ERK:A2a mutant $(\boldsymbol{H})$ animals. $\boldsymbol{I}$, Quantitative analysis demonstrating a significant decrease in the percentage of D2R-MSNs that upregulate ARC in ERK:A2a mutant mice ${ }^{*} p<0.05 ; n=3$ mice/genotype; $200-250$ cells/mouse). All data are presented as mean \pm SEM. Scale bars, $50 \mu \mathrm{m}$; inset, $20 \mu \mathrm{m}$.

porter mice, which label all Cre-expressing cells with tdTomato fluorescent protein (Madisen et al., 2010). We then crossed these A2a-Cre; Ai9 mice with D2-GFP BAC-transgenic mice, which express GFP in all D2R-expressing cells (Gong et al., 2007) (Fig. 7C). The proportion of cells that expressed D2R-only (green), A2a-only (red), or coexpressed both (A2a/D2; yellow) were then quantified at multiple postnatal stages (Fig. 7D). At P14, approximately one-third of labeled cells were D2 only $(32.02 \pm 7.61 \%)$, one-third were A2a only $(34.51 \pm 3.55 \%)$, and the remaining one-third coexpressed A2a and D2 (33.47 $\pm 6.52 \%$; Fig. 7D). At $\mathrm{P} 21$, we observed an increase in A2a/D2 coexpression, however nearly $25 \%$ of cells still did not show A2a recombination (D2 only: $26.33 \pm 4.88 \%$; A2a only: $12.62 \pm 1.21 \%$; A2a + D2:
$61.05 \pm 3.74 \%$; Fig. 7D). By P28, 15\% of D2R-expressing cells still had not undergone A2a-Cre-mediated recombination (D2 only: $14.45 \pm 5.06 \%$; A2a only: $7.58 \pm 1.08 \%$; A2a + D2: $77.97 \pm 6.13 \%$; Fig. $7 D$ ). This result demonstrates that the A2a-Cre mouse line is delayed in inducing genetic recombination in D2R-MSNs during striatal development.

\section{Discussion}

ERK signaling is essential for MSN-pathway-specific motor functions

The functions of ERK signaling in the striatum have been the focus of numerous investigations due to the hypothesized importance of the pathway in normal striatal functions and in disease 
A

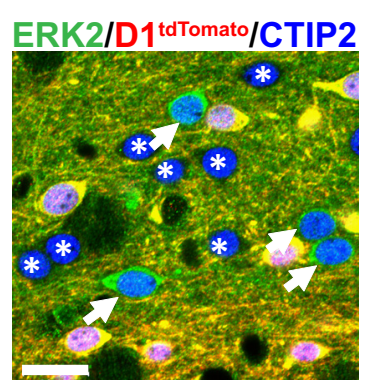

C

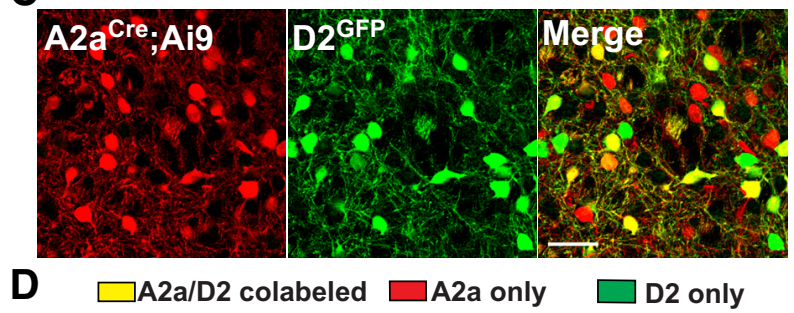

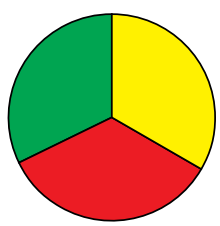

P14

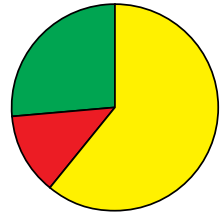

P21
B

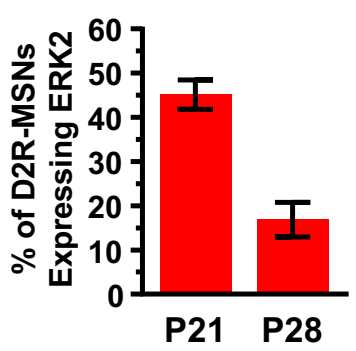

Figure 7. Delayed loss of ERK activity in ERK:A2a mice. $\boldsymbol{A}$, Representative image of P21 ERK:A2a striatum. CTIP2 (blue) labels all MSNs, whereas D2R-MSNs are identified as negative for D1 ${ }^{\text {tdTomato }}$ expression (red). A subpopulation of D2R-MSNs in ERK:A2a mutants maintain ERK2 expression (green, white arrows). ERK2-deficient D2R-MSNs are indicated with a white asterisk. Scale bar, $20 \mu \mathrm{m}$. B, Quantitative analysis of ERK2 expression in P21 and P28 ERK:A2a striatum. Approximately half of all D2R-MSNs maintain ERK2 expression at P21. By $28, \sim 15 \%$ of D2RMSNs continue to express ERK2. ( $n=3$ animals/genotype; 500-600cells/animal). C, Colocalization of D2 ${ }^{\text {GFP }}$ (green) and A2a ${ }^{\text {Cre: }}$ Ai9 (red) at P14. Scale bar, $50 \mu \mathrm{m}$. D, Quantification of $\mathrm{D} 2{ }^{\mathrm{GFP}}$ and $\mathrm{A} 2 \mathrm{a}{ }^{\mathrm{Cre}}$ :Ai9 colocalization at P14, P21, and P28. All data are presented as a percentage of total D2R-MSNs counted. Note that the percentage of D2R-MSNs that express both GFP and Ai9 is low at P14. The percentage increases over time, but complete recombination in D2R-MSNs is not observed, even by P28 ( $n=3$ animals/time point; $500-600$ cells/animal). All data are presented as mean \pm SEM.

states (Fasano and Brambilla, 2011; Cerovic et al., 2013). Here, we present the first genetic evidence that cell-type-specific elimination of ERK activity markedly impairs striatal pathway specific motor functions. The severity of these phenotypes presumably reflects the fact that multiple external stimuli (including neurotransmitters and growth factors) and intrinsic neural activity act via ERK to regulate MSN functions.

Deletion of both ERK1 and ERK2 in D2R-MSNs results in a pronounced and long-lasting hyperlocomotor phenotype. The intensity of this phenotype was unexpected given that germline ERK1-KO mice show molecular and behavioral phenotypes indicative of increased neuronal activity and ERK2-hypomorphic mice fail to show locomotor defects (Selcher et al., 2001; Mazzucchelli et al., 2002; Ferguson et al., 2006; Satoh et al., 2007; Engel et al., 2009). However, our results are entirely consistent with studies showing that specific ablation of D2R-MSNs leads to marked hyperlocomotor activity (Saito et al., 2001; Sano et al., 2003; Durieux et al., 2009). ERK:D2 mice are also insensitive to the cataleptic effects of haloperidol, a response mediated by D2R-MSNs (Sanberg, 1980; Farde et al., 1992). This insensitivity to haloperidol is also consistent with results obtained using genetic ablation of D2R-MSNs (Durieux et al., 2012).
Given that ERK:D2 mice show no evidence of cell death in the striatum and that D2R-MSN axonal projections are appropriately targeted and maintained, our data suggest that the behavioral phenotypes observed are a result of dramatically reduced functionality of D2R-MSNs. The hypolocomotive phenotype in ERK:D1 mice also recapitulates D1R-MSN ablation, suggesting that ERK activity is necessary for the proper function of both MSN populations (Drago et al., 1998; Durieux et al., 2012; Révy et al., 2014).

The dramatic decline in health and early lethality of ERK:D1 mice precluded a full analysis of this line. The changes in bodyweight and movement after the first postnatal week are consistent with previous findings in both dopamine-deficient mice and knock-out models using D1-Cre (Zhou and Palmiter, 1995; Kozorovitskiy et al., 2012). Presumably, ERK:D1 pups cannot acquire nourishment during and after weaning.

\section{ERK activity is required for D2R-MSN excitability}

ERK:D2 mice exhibit a significantly reduced density of dendritic spines on D2R-MSNs. Previous studies using genetic ERK models did not observe spine alterations (Satoh et al., 2007). Further, D2R-specific knock-outs of BDNF-TrkB, an upstream activator of ERK, failed to induce spine changes (Lobo et al., 2010; Besusso et al., 2013). Coincidently, these BDNF-TrkB models also fail to show locomotor changes until at least 1 year of age (Besusso et al., 2013). Therefore, loss of ERK in D2R-MSNs leads to more striking defects in spinogenesis, as well as more dramatic changes in locomotion, than does loss of BDNF/TrkB.

Changes in dendritic spine density are known to be associated with changes in mEPSCs (Segal, 2005). Consistent with this idea, D2R-MSNs from ERK:D2 mice exhibited a marked reduction in the frequency of mEPSCs. These data suggest reduced excitatory synaptic connectivity in D2R-MSNs. However, we cannot exclude that changes in presynaptic release are also involved. This striking change in synaptic efficacy has the potential to disrupt patterned activity derived from cortical and thalamic excitatory input onto D2R striatal neurons. The observed reduction in frequency and amplitude of mIPSCs would have the potential to further disrupt D2R-MSN circuit functions.

In addition to reduced synaptic strength, we observed a dramatic reduction in the intrinsic excitability of ERK-deficient D2R-MSNs. Mechanisms that might explain this phenotype include loss of ERK-mediated phosphorylation of metabotropic or ionotropic receptors or voltage gated ion channels (Sweatt, 2004). For example, ERK phosphorylation regulates dendritic localization of the voltage-gated potassium channel Kv4.2, which is expressed abundantly in D2R-MSNs and serves to dampen neuronal excitability (Adams et al., 2000; Yuan et al., 2002; Day et al., 2008). Loss of ERK might lead to increased surface expression of Kv4.2 and decreased neuronal excitability. Interestingly, in a recent study of P14 excitatory cortical pyramidal neurons, conditional ERK deletion resulted in hyperexcitability (Xing et al., 2016). Whether these distinct effects on excitability represent differences in ERK regulation in excitatory versus inhibitory neurons or differences in the developmental stages studied is unclear at present.

Regardless of mechanisms, the reductions of synaptic efficacy and neuronal excitability observed in D2R-MSNs would likely impair the functioning of D2R-MSNs in governing motor behavior. These effects on excitability may well explain the marked hyperlocomotor activity that we observed in ERK:D2 mice. Furthermore these changes are potentially relevant to a number of pathological states. For example, if similar ERK regulation of excitability 
occurs in D1R-MSNs, it would be relevant to L-Dopa-induced dyskinesia, which is known to be associated with striking increases in ERK activity (Gerfen et al., 2002; Feyder et al., 2011). We note that that there may be differences in ERK regulation between D1R-MSN and D2R-MSNs. Indeed, it has been shown that the PKA-dependent phosphorylation of histone $\mathrm{H} 3$ in response to cell stimulation is ERK dependent in D1R-MSNs but ERK independent in D2R-MSNs (Bertran-Gonzalez et al., 2009).

\section{Expression of activity-regulated genes}

Previous pharmacological and genetic studies investigating ERK involvement in striatal activity-induced gene expression produced conflicting results. For instance, pan-striatal pharmacological blockade of ERK activity reduced activity-induced gene expression in the striatum (Sgambato et al., 1998; Vanhoutte et al., 1999; Zanassi et al., 2001), whereas germline ERK1 knock-out mice showed increased IEG expression in the striatum (Mazzucchelli et al., 2002; Ferguson et al., 2006). Our cell-type-specific ablation of ERK activity in D2R-MSNs clearly demonstrate a strong reduction of activity-regulated gene expression in D2RMSNs. Gene expression profiling at P17 showed markedly reduced expression of IEGs and synaptic plasticity genes in ERK:D2 mutant mice. We extended these observations using haloperidol administration, which normally elicits strong activity-induced expression of these genes (Bertran-Gonzalez et al., 2008). Even upon stimulation with haloperidol, IEG gene expression was largely abrogated in D2R-MSNs. Therefore, our data demonstrate that ERK is critical for activity-induced gene expression in MSNs in vivo, a process that is essential for driving neuronal synaptic plasticity and adaptations in basal ganglia circuits (Flavell and Greenberg, 2008; West and Greenberg, 2011).

ERK is thought to control activity-mediated gene expression via activation of a number of critical transcription factors (Girault et al., 2007). However, in ERK-deficient D2R MSNs, it remains unclear whether the reduction in activity-induced gene expression is a direct effect of ERK pathway transcriptional regulation or if the reduced neuronal excitability in the ERK-deleted MSNs also plays a role. ERK deficiency may also impair translation of local mRNA stores in response to stimuli (O'Donnell et al., 2012). Finally, effects of ERK deficiency could be due to regulation of developmental events (see below). Future studies that ablate ERK activity inducibly will be important in further defining ERK-dependent mechanisms in adult MSNs.

\section{Differences in phenotypes between Adora2a- and D2-Cre ERK-deficient mice}

Our studies show a concordance of phenotypes between ERK:D2 mice and ERK:A2a mice in regard to their resistance to haloperidolinduced catalepsy and loss of activity-induced gene expression. A surprising result is that ERK:A2a mice do not exhibit the hyperlocomotor phenotype seen in the ERK:D2 mouse line. A possible explanation is related to different patterns of recombination between the D2-Cre and A2a-Cre mouse lines. Although D2-Cre mice target a small population of cholinergic interneurons in the striatum, A2a-Cre-transgenic mice reportedly do not target the cholinergic population (Durieux et al., 2009; Kozorovitskiy et al., 2012; Kharkwal et al., 2016). However, preservation of ERK in cholinergic neurons in the A2a line is unlikely to account for the behavioral difference because cholinergic interneurons ultimately act on the MSN population. For example, a recent study showed that haloperidol-induced changes in cholinergic neuron activity were relayed directly to D2R-MSNs to mediate cataleptic effects (Kharkwal et al., 2016).
A more likely explanation for the different observed behaviors is the temporal delay in Cre-mediated ERK2 deletion in the ERK: A2a mice. At P21, nearly $45 \%$ of D2R-MSNs continue to express ERK2 in ERK:A2a mice compared with only 3\% in ERK:D2 mutants. Even at P28, almost 20\% of D2R-MSNs still express ERK in A2a-Cre mice. These findings argue that the loss of ERK activity specifically in D2R-MSNs before or during the "critical period" of network formation (Tepper et al., 1998; Kozorovitskiy et al., 2012) results in hyperlocomotor behavior, whereas loss after the critical period results in a milder phenotype. Therefore, reductions in ERK/MAP activity before or during the critical period may lead to long-lasting modifications of circuit function and behavioral abnormalities. This concept may be pertinent to the etiology of developmental hyperkinetic disorders such as attention deficit hyperactivity disorder (Faraone et al., 2015; Rosenberg et al., 2016). The observation that ERK:A2a mice, which exhibit delayed recombination, show impaired expression of activity-regulated genes in response to haloperidol in adulthood underscores the importance of ERK functions in neural plasticity even beyond the critical period.

\section{References}

Adams JP, Anderson AE, Varga AW, Dineley KT, Cook RG, Pfaffinger PJ, Sweatt JD (2000) The A-type potassium channel Kv4.2 is a substrate for the mitogen-activated protein kinase ERK. J Neurochem 75:2277-2287. Medline

Ade KK, Wan Y, Chen M, Gloss B, Calakos N (2011) An improved BAC transgenic fluorescent reporter line for sensitive and specific identification of striatonigral medium spiny neurons. Front Syst Neurosci 5:32. CrossRef Medline

Alonso M, Medina JH, Pozzo-Miller L (2004) ERK1/2 activation is necessary for BDNF to increase dendritic spine density in hippocampal CA1 pyramidal neurons. Learn Mem 11:172-178. CrossRef Medline

Arlotta P, Molyneaux BJ, Jabaudon D, Yoshida Y, Macklis JD (2008) Ctip2 controls the differentiation of medium spiny neurons and the establishment of the cellular architecture of the striatum. J Neurosci 28:622-632. CrossRef Medline

Bertran-Gonzalez J, Bosch C, Maroteaux M, Matamales M, Hervé D, Valjent E, Girault JA (2008) Opposing patterns of signaling activation in dopamine D1 and D2 receptor-expressing striatal neurons in response to cocaine and haloperidol. J Neurosci 28:5671-5685. CrossRef Medline

Bertran-Gonzalez J, Håkansson K, Borgkvist A, Irinopoulou T, BramiCherrier K, Usiello A, Greengard P, Hervé D, Girault JA, Valjent E, Fisone G (2009) Histone $\mathrm{H} 3$ phosphorylation is under the opposite tonic control of dopamine D2 and adenosine A2A receptors in striatopallidal neurons. Neuropsychopharmacology 34:1710-1720. CrossRef Medline

Besusso D, Geibel M, Kramer D, Schneider T, Pendolino V, Picconi B, Calabresi P, Bannerman DM, Minichiello L (2013) BDNF-TrkB signaling in striatopallidal neurons controls inhibition of locomotor behavior. Nat Commun 4:2031. CrossRef Medline

Bonito-Oliva A, Feyder M, Fisone G (2011) Deciphering the actions of antiparkinsonian and antipsychotic drugs on cAMP/DARPP-32 signaling. Front Neuroanat 5:38. CrossRef Medline

Bureau G, Carrier M, Lebel M, Cyr M (2010) Intrastriatal inhibition of extracellular signal-regulated kinases impaired the consolidation phase of motor skill learning. Neurobiol Learn Mem 94:107-115. CrossRef Medline

Calabresi P, Picconi B, Tozzi A, Ghiglieri V, Di Filippo M (2014) Direct and indirect pathways of basal ganglia: a critical reappraisal. Nat Neurosci 17:1022-1030. CrossRef Medline

Cargnello M, Roux PP (2011) Activation and function of the MAPKs and their substrates, the MAPK-activated protein kinases. Microbiol Mol Biol Rev 75:50-83. CrossRef Medline

Cerovic M, d'Isa R, Tonini R, Brambilla R (2013) Molecular and cellular mechanisms of dopamine-mediated behavioral plasticity in the striatum. Neurobiol Learn Mem 105:63-80. CrossRef Medline

Chen Y, Wang Y, Ertürk A, Kallop D, Jiang Z, Weimer RM, Kaminker J, Sheng M (2014) Activity-induced Nr4al regulates spine density and distribution pattern of excitatory synapses in pyramidal neurons. Neuron 83:431443. CrossRef Medline 
Day M, Wokosin D, Plotkin JL, Tian X, Surmeier DJ (2008) Differential excitability and modulation of striatal medium spiny neuron dendrites. J Neurosci 28:11603-11614. CrossRef Medline

Drago J, Padungchaichot P, Wong JY, Lawrence AJ, McManus JF, Sumarsono SH, Natoli AL, Lakso M, Wreford N, Westphal H, Kola I, Finkelstein DI (1998) Targeted expression of a toxin gene to D1 dopamine receptor neurons by cre-mediated site-specific recombination. J Neurosci 18: 9845-9857. Medline

Durieux PF, Bearzatto B, Guiducci S, Buch T, Waisman A, Zoli M, Schiffmann SN, de Kerchove d'Exaerde A (2009) D2R striatopallidal neurons inhibit both locomotor and drug reward processes. Nat Neurosci 12:393395. CrossRef Medline

Durieux PF, Schiffmann SN, de Kerchove d'Exaerde A (2012) Differential regulation of motor control and response to dopaminergic drugs by D1R and D2R neurons in distinct dorsal striatum subregions. EMBO J 31:640 653. CrossRef Medline

Durieux PF, Schiffmann SN, de Kerchove d'Exaerde A (2011) Targeting neuronal populations of the striatum. Front Neuroanat 5:40. CrossRef Medline

Edgar R, Domrachev M, Lash AE (2002) Gene Expression Omnibus: NCBI gene expression and hybridization array data repository. Nucleic Acids Res 30:207-210. CrossRef Medline

Engel SR, Creson TK, Hao Y, Shen Y, Maeng S, Nekrasova T, Landreth GE, Manji HK, Chen G (2009) The extracellular signal-regulated kinase pathway contributes to the control of behavioral excitement. Mol Psychiatry 14:448-461. CrossRef Medline

Faraone SV, Asherson P, Banaschewski T, Biederman J, Buitelaar JK, RamosQuiroga JA, Rohde LA, Sonuga-Barke EJ, Tannock R, Franke B (2015) Attention-deficit/hyperactivity disorder. Nat Rev Dis Primers 1:15020. CrossRef Medline

Farde L, Nordström AL, Wiesel FA, Pauli S, Halldin C, Sedvall G (1992) Positron emission tomographic analysis of central D1 and D2 dopamine receptor occupancy in patients treated with classical neuroleptics and clozapine: relation to extrapyramidal side effects. Arch Gen Psychiatry 49:538-544. CrossRef Medline

Farrell MS, Pei Y, Wan Y, Yadav PN, Daigle TL, Urban DJ, Lee HM, Sciaky N, Simmons A, Nonneman RJ, Huang XP, Hufeisen SJ, Guettier JM, Moy SS, Wess J, Caron MG, Calakos N, Roth BL (2013) A G[alpha]s DREADD mouse for selective modulation of cAMP production in striatopallidal neurons. Neuropsychopharmacology 38:854-862. CrossRef Medline

Fasano S, Brambilla R (2011) Ras-ERK signaling in behavior: old questions and new perspectives. Front Behav Neurosci 5:79. CrossRef Medline

Ferguson SM, Fasano S, Yang P, Brambilla R, Robinson TE (2006) Knockout of ERK1 enhances cocaine-evoked immediate early gene expression and behavioral plasticity. Neuropsychopharmacology 31:2660-2668. CrossRef Medline

Feyder M, Bonito-Oliva A, Fisone G (2011) L-DOPA-induced dyskinesia and abnormal signaling in striatal medium spiny neurons: focus on dopamine D1 receptor-mediated transmission. Front Behav Neurosci 5:71. CrossRef Medline

Flavell SW, Greenberg ME (2008) Signaling mechanisms linking neuronal activity to gene expression and plasticity of the nervous system. Annu Rev Neurosci 31:563-590. CrossRef Medline

Gerfen CR, Engber TM, Mahan LC, Susel Z, Chase TN, Monsma FJ Jr, Sibley DR (1990) D1 and D2 dopamine receptor-regulated gene expression of striatonigral and striatopallidal neurons. Science 250:1429-1432. CrossRef Medline

Gerfen CR, Miyachi S, Paletzki R, Brown P (2002) D1 dopamine receptor supersensitivity in the dopamine-depleted striatum results from a switch in the regulation of ERK1/2/MAP kinase. J Neurosci 22:5042-5054. Medline

Girault JA, Valjent E, Caboche J, Hervé D (2007) ERK2: a logical AND gate critical for drug-induced plasticity? Curr Opin Pharmacol 7:77-85. CrossRef Medline

Goldin M, Segal M (2003) Protein kinase C and ERK involvement in dendritic spine plasticity in cultured rodent hippocampal neurons. Eur J Neurosci 17:2529-2539. CrossRef Medline

Gong S, Doughty M, Harbaugh CR, Cummins A, Hatten ME, Heintz N, Gerfen CR (2007) Targeting Cre recombinase to specific neuron populations with bacterial artificial chromosome constructs. J Neurosci 27: 9817-9823. CrossRef Medline
Graybiel AM, Grafton ST (2015) The striatum: where skills and habits meet. Cold Spring Harb Perspect Biol 7:a021691. CrossRef Medline

Hikida T, Kimura K, Wada N, Funabiki K, Nakanishi S (2010) Distinct roles of synaptic transmission in direct and indirect striatal pathways to reward and aversive behavior. Neuron 66:896-907. CrossRef Medline

Kawaguchi Y, Wilson CJ, Emson PC (1990) Projection subtypes of rat neostriatal matrix cells revealed by intracellular injection of biocytin. J Neurosci 10:3421-3438. Medline

Kharkwal G, Brami-Cherrier K, Lizardi-Ortiz JE, Nelson AB, Ramos M, Del Barrio D, Sulzer D, Kreitzer AC, Borrelli E (2016) Parkinsonism driven by antipsychotics originates from dopaminergic control of striatal cholinergic interneurons. Neuron 91:67-78. CrossRef Medline

Kozorovitskiy Y, Saunders A, Johnson CA, Lowell BB, Sabatini BL (2012) Recurrent network activity drives striatal synaptogenesis. Nature 485: 646-650. CrossRef Medline

Krapivinsky G, Krapivinsky L, Manasian Y, Ivanov A, Tyzio R, Pellegrino C, Ben-Ari Y, Clapham DE, Medina I (2003) The NMDA receptor is coupled to the ERK pathway by a direct interaction between NR2B and RasGRF1. Neuron 40:775-784. CrossRef Medline

Kravitz AV, Freeze BS, Parker PR, Kay K, Thwin MT, Deisseroth K, Kreitzer AC (2010) Regulation of parkinsonian motor behaviours by optogenetic control of basal ganglia circuitry. Nature 466:622-626. CrossRef Medline

Li Y, Yui D, Luikart BW, McKay RM, Li Y, Rubenstein JL, Parada LF (2012) Conditional ablation of brain-derived neurotrophic factor-TrkB signaling impairs striatal neuron development. Proc Natl Acad Sci U S A 109: 15491-15496. CrossRef Medline

Lobo MK, Covington HE 3rd, Chaudhury D, Friedman AK, Sun H, DamezWerno D, Dietz DM, Zaman S, Koo JW, Kennedy PJ, Mouzon E, Mogri M, Neve RL, Deisseroth K, Han MH, Nestler EJ (2010) Cell type-specific loss of BDNF signaling mimics optogenetic control of cocaine reward. Science 330:385-390. CrossRef Medline

Madisen L, Zwingman TA, Sunkin SM, Oh SW, Zariwala HA, Gu H, Ng LL, Palmiter RD, Hawrylycz MJ, Jones AR, Lein ES, Zeng H (2010) A robust and high-throughput Cre reporting and characterization system for the whole mouse brain. Nat Neurosci 13:133-140. CrossRef Medline

Mao L, Tang Q, Samdani S, Liu Z, Wang JQ (2004) Regulation of MAPK/ ERK phosphorylation via ionotropic glutamate receptors in cultured rat striatal neurons. Eur J Neurosci 19:1207-1216. CrossRef Medline

Mazzucchelli C, Vantaggiato C, Ciamei A, Fasano S, Pakhotin P, Krezel W, Welzl H, Wolfer DP, Pagès G, Valverde O, Marowsky A, Porrazzo A, Orban PC, Maldonado R, Ehrengruber MU, Cestari V, Lipp HP, Chapman PF, Pouysségur J, Brambilla R (2002) Knockout of ERK1 MAP kinase enhances synaptic plasticity in the striatum and facilitates striatalmediated learning and memory. Neuron 34:807-820. CrossRef Medline

Nekrasova T, Shive C, Gao Y, Kawamura K, Guardia R, Landreth G, Forsthuber TG (2005) ERK1-deficient mice show normal T cell effector function and are highly susceptible to experimental autoimmune encephalomyelitis. J Immunol 175:2374-2380. CrossRef Medline

Nelson AB, Kreitzer AC (2014) Reassessing models of basal ganglia function and dysfunction. Annu Rev Neurosci 37:117-135. CrossRef Medline

O’Donnell A, Odrowaz Z, Sharrocks AD (2012) Immediate-early gene activation by the MAPK pathways: what do and don't we know? Biochem Soc Trans 40:58-66. CrossRef Medline

Okuno H (2011) Regulation and function of immediate-early genes in the brain: beyond neuronal activity markers. Neurosci Res 69:175-186. CrossRef Medline

Pascoli V, Cahill E, Bellivier F, Caboche J, Vanhoutte P (2014) Extracellular signal-regulated protein kinases 1 and 2 activation by addictive drugs: a signal toward pathological adaptation. Biol Psychiatry 76:917-926. CrossRef Medline

Révy D, Jaouen F, Salin P, Melon C, Chabbert D, Tafi E, Concetta L, Langa F, Amalric M, Kerkerian-Le Goff L, Marie H, Beurrier C (2014) Cellular and behavioral outcomes of dorsal striatonigral neuron ablation: new insights into striatal functions. Neuropsychopharmacology 39:26622672. CrossRef Medline

Robertson GS, Vincent SR, Fibiger HC (1992) D1 and D2 dopamine receptors differentially regulate $\mathrm{c}$-fos expression in striatonigral and striatopallidal neurons. Neuroscience 49:285-296. CrossRef Medline

Rosenberg MD, Finn ES, Scheinost D, Papademetris X, Shen X, Constable RT, Chun MM (2016) A neuromarker of sustained attention from whole-brain functional connectivity. Nat Neurosci 19:165-171. CrossRef Medline 
Saito M, Iwawaki T, Taya C, Yonekawa H, Noda M, Inui Y, Mekada E, Kimata Y, Tsuru A, Kohno K (2001) Diphtheria toxin receptor-mediated conditional and targeted cell ablation in transgenic mice. Nat Biotechnol 19:746-750. CrossRef Medline

Samuels IS, Karlo JC, Faruzzi AN, Pickering K, Herrup K, Sweatt JD, Saitta SC, Landreth GE (2008) Deletion of ERK2 mitogen-activated protein kinase identifies its key roles in cortical neurogenesis and cognitive function. J Neurosci 28:6983-6995. CrossRef Medline

Sanberg PR (1980) Haloperidol-induced catalepsy is mediated by postsynaptic dopamine receptors. Nature 284:472-473. CrossRef Medline

Sano H, Yasoshima Y, Matsushita N, Kaneko T, Kohno K, Pastan I, Kobayashi K (2003) Conditional ablation of striatal neuronal types containing dopamine D2 receptor disturbs coordination of basal ganglia function. J Neurosci 23:9078-9088. Medline

Satoh Y, Endo S, Ikeda T, Yamada K, Ito M, Kuroki M, Hiramoto T, Imamura O, Kobayashi Y, Watanabe Y, Itohara S, Takishima K (2007) Extracellular signal-regulated kinase 2 (ERK2) knockdown mice show deficits in long-term memory; ERK2 has a specific function in learning and memory. J Neurosci 27:10765-10776. CrossRef Medline

Segal M (2005) Dendritic spines and long-term plasticity. Nat Rev Neurosci 6:277-284. CrossRef Medline

Selcher JC, Nekrasova T, Paylor R, Landreth GE, Sweatt JD (2001) Mice lacking the ERK1 isoform of MAP kinase are unimpaired in emotional learning. Learn Mem 8:11-19. CrossRef Medline

Sgambato V, Pagès C, Rogard M, Besson MJ, Caboche J (1998) Extracellular signal-regulated kinase (ERK) controls immediate early gene induction on corticostriatal stimulation. J Neurosci 18:8814-8825. Medline

Shiflett MW, Balleine BW (2011) Contributions of ERK signaling in the striatum to instrumental learning and performance. Behav Brain Res 218: 240-247. CrossRef Medline

Shiflett MW, Brown RA, Balleine BW (2010) Acquisition and performance of goal-directed instrumental actions depends on ERK signaling in distinct regions of dorsal striatum in rats. J Neurosci 30:2951-2959. CrossRef Medline

Surmeier DJ, Ding J, Day M, Wang Z, Shen W (2007) D1 and D2 dopamine- receptor modulation of striatal glutamatergic signaling in striatal medium spiny neurons. Trends Neurosci 30:228-235. CrossRef Medline

Sweatt JD (2004) Mitogen-activated protein kinases in synaptic plasticity and memory. Curr Opin Neurobiol 14:311-317. CrossRef Medline

Tepper JM, Sharpe NA, Koós TZ, Trent F (1998) Postnatal development of the rat neostriatum: electrophysiological, light- and electron-microscopic studies. Dev Neurosci 20:125-145. CrossRef Medline

Thomas GM, Huganir RL (2004) MAPK cascade signalling and synaptic plasticity. Nat Rev Neurosci 5:173-183. CrossRef Medline

Valjent E, Pascoli V, Svenningsson P, Paul S, Enslen H, Corvol JC, Stipanovich A, Caboche J, Lombroso PJ, Nairn AC, Greengard P, Hervé D, Girault JA (2005) Regulation of a protein phosphatase cascade allows convergent dopamine and glutamate signals to activate ERK in the striatum. Proc Natl Acad Sci U S A 102:491-496. CrossRef Medline

Vanhoutte P, Barnier JV, Guibert B, Pagès C, Besson MJ, Hipskind RA, Caboche J (1999) Glutamate induces phosphorylation of Elk-1 and CREB, along with c-fos activation, via an extracellular signal-regulated kinasedependent pathway in brain slices. Mol Cell Biol 19:136-146. CrossRef Medline

West AE, Greenberg ME (2011) Neuronal activity-regulated gene transcription in synapse development and cognitive function. Cold Spring Harb Perspect Biol 3:pii:a005744. CrossRef Medline

Xing L, Larsen RS, Bjorklund GR, Li X, Wu Y, Philpot BD, Snider WD, Newbern JM (2016) Layer specific and general requirements for ERK/ MAPK signaling in the developing neocortex. eLife 5: pii: e11123. CrossRef Medline

Yuan LL, Adams JP, Swank M, Sweatt JD, Johnston D (2002) Protein kinase modulation of dendritic $\mathrm{K}+$ channels in hippocampus involves a mitogenactivated protein kinase pathway. J Neurosci 22:4860-4868. Medline

Zanassi P, Paolillo M, Feliciello A, Avvedimento EV, Gallo V, Schinelli S (2001) cAMP-dependent protein kinase induces cAMP-response elementbinding protein phosphorylation via an intracellular calcium release/ ERK-dependent pathway in striatal neurons. J Biol Chem 276:1148711495. CrossRef Medline

Zhou QY, Palmiter RD (1995) Dopamine-deficient mice are severely hypoactive, adipsic, and aphagic. Cell 83:1197-1209. CrossRef Medline 